\title{
The Drivers of Income Inequality in Rich Countries
}

\author{
Brian Nolan $\dagger^{1}$, Matteo G. Richiardi ${ }^{2}$, and Luis Valenzuela ${ }^{1}$ \\ ${ }^{1}$ Institute for New Economic Thinking at the Oxford Martin School, Department of Social Policy and Intervention, \\ and Nuffield College, University of Oxford \\ ${ }^{2}$ Institute for Economic and Social Research, University of Essex and Collegio Carlo Alberto, Turin
}

\begin{abstract}
Rising income inequality has recently come centre-stage as a core societal concern for rich countries. The diagnosis of the forces driving inequality upwards and their relative importance remains hotly contested, notably with respect to the roles of globalization versus technology and of market forces versus institutions and policy choices. This survey provides a critical review and synthesis of recent research. The focus is on income inequality across the entire distribution, rather than only on what has been happening at the very top. We pay particular attention to including what has been learned from the analysis of micro-data, to ensuring that the coverage is not unduly US-centric, and to analyses of the interrelations between the different drivers of inequality. The marked differences in inequality trends across countries and time-periods reflect how global economic forces such as globalisation and technological change have interacted with differing national contexts and institutions. Major analytical challenges stand in the way of a consensus emerging on the relative importance of different drivers in how income inequality has evolved in recent decades.
\end{abstract}

KEYWORDS: inequality, wage dispersion, technology, globalisation, market power.

JEL Classification: D30, J00, D40, F16, F66, H20. 


\section{Introduction}

Rising income inequality has recently come centre-stage as a core societal concern for rich countries, being blamed for a quite remarkable range of their current economic, social and political ills. Despite being the focus of a substantial body of research, the diagnosis of the forces driving inequality upwards and their relative importance remains hotly contested, notably with respect to the roles of globalization versus technology and of market forces versus institutions and policy choices. This survey provides a critical review and synthesis of recent research on the drivers of income inequality in rich countries, and in doing so highlights gaps in knowledge and what stands in the way of a consensus emerging about the relative importance of the various drivers.

In contrast to studies on the evolution of global inequality and its drivers, such as Bourguignon (2015), Milanovic (2016) and Ravallion (2018), the focus of this survey is on the rich countries where recent trends have aroused such interest. While income inequality has also risen in some emerging and developing countries in recent decades, trends have been more varied with for example striking declines in inequality in Latin America (see for example Bustillo et al, 2018, Alvaredo and Gasparini, 2015). The rich countries are distinctive in terms of inequality levels and trends, as well as institutions and economic structures (see Bourguignon, 2015; Alvaredo et al, 2018) The impact which potential drivers such as globalization and technology would be expected to have on inequality in rich versus emerging and developing countries, with their differing endowments in terms of capital and skilled versus unskilled labour, would also be expected to differ (e.g. Freeman, 2011; Dabla-Norris et al, 2015; Kanbur, 2015). This provides the rationale for the concentration of this survey on them. (While inequality in wealth has also been on the rise in many rich countries, research on that related but distinct topic merits a separate review and is not covered here.)

We cover what has been driving income inequality across the entire distribution, rather than only what has been happening at the very top, which has played a dominant role in research and debate for the last decade, since the pioneering collaborative work led by Atkinson and Piketty (2007, 2010) (see also Atkinson, Piketty and Saez 2011). Our focus is on the period from about 1980, reflecting the availability of comparable data for the entire distribution across the rich countries, rather than the much longer span covered by estimates of top income shares; this still allows us to cover the period during which inequality has been seen to rise in many rich countries.

Our coverage of the literature is necessarily selective, not only in its focus on the rich countries but in concentrating in particular on capturing the most recent developments in the literature over the last decade (with about half the studies we reference being since the valuable review of research at aggregate country level by Forster and Toth (2015); in reflecting particularly on what has been learned from the analysis of micro-data; in ensuring that the coverage is not unduly US-centric; and in paying particular attention to studies seeking to tease out the interrelations between the different drivers of inequality.

We first present in Section 2 key figures on how income inequality has evolved over recent decades across the rich countries, covering both inequality across the distribution as a whole and also the share going to the top of the distribution, since the latter plays a key role in debates about what has been happening to, and driving, rising inequality.

Research across the social sciences has identified a very wide variety of forces thought to be implicated in increasing inequality in the rich countries. Section 3 then reviews in some depth the literature on the impact of individual drivers and pathways on inequality, covering globalisation, technological change, finance and macroeconomic shocks, labour market institutions and labour market power, product market power, re-distribution via social protection transfers and direct 
taxes, and demography/household composition. Section 4 then sets out a framework within which these factors and the inter-relationships between them can be seen, and reviews efforts to arrive at an overall assessment of their relative importance in how inequality has evolved across the rich countries. This brings out that while recent research is rich in partial analysis focusing on specific determinants, studies evaluating the contributions of the main factors at work come to quite different conclusions about which dominate. We bring out how this arises, and the nature of the challenges such studies face in seeking to incorporate the range of potential factors and interactions between them. We conclude by highlighting potentially productive directions for future research in that light.

\section{What has actually happened to income inequality in rich countries since 1980 ?}

To see how income inequality has evolved over recent decades across the rich countries, we first focus on inequality across the distribution as a whole, using evidence mostly drawn from household surveys. The income concept conventionally employed in this context is disposable household income, that is income from the market plus cash transfers minus direct taxes and employee social insurance contributions. (This includes both wages and income from other sources; we refer to the former as 'wages' or 'earnings' throughout.) As is also conventional, this is adjusted for differences in household size and the economies of scales from living together by the use of equivalence scales to derive equivalised income; for this purpose we adopt the most widely used approach in comparative research, which is to divide total household income by the square root of household size. We also focus on the most commonly-used summary measure of inequality, the Gini coefficient. This is most sensitive to changes around the middle of the distribution, and other summary inequality measures may not always show the same patterns (as illustrated for example by Milanovic and Weide 2018, for the US), but is by far the most widely used measure in the empirical literature; in assessing trends we complement it by also looking directly at what has happened at the top of the distribution.

To assess trends in inequality across countries, we rely in the first instance on the Luxembourg Income Study (LIS) database and the OECD Income Distribution and Poverty database. These are designed to allow comparative research on inequality and have been widely used for that purpose; LIS has been employed in seminal studies of inequality and poverty such as Atkinson, Rainwater and Smeeding (1995) and Gornick and Jäntti (2013), while the OECD database has been central to OECD publications on inequality and poverty such as Growing Unequal (2008), Divided We Stand (2011) and In It Together (2015). (The EU's harmonised EU-SILC microdata do not go back as far as these databases, but data from that source are incorporated into both.) LIS mostly has data in 'waves', that is for occasional years around 1975, 1980, 1985 etc. at approximately 5-year intervals; the OECD database initially gathered figures at intervals for around 1980, 1985, etc, but has annual data for more recent years. However, the LIS and OECD databases often differ in how far back they allow one to go, and this is often not as far back as 1980. With LIS the first observation for quite a few countries is no earlier than the 1990s, and for the OECD, this is even more pronounced, with a substantial number of the countries covered having data only from 2004 onwards. ${ }^{1}$ Here we

\footnotetext{
${ }^{1}$ Detailed information on the LIS database is available at http / /www.lisdatacenter.org, and a review is provided by Ravallion (2015); detailed information on the OECD database is at http //www.oecd.org/social/
} 
use the source that allows us to go furthest back for each country, which is LIS except for Canada, Greece, Japan, Netherlands, New Zealand, Portugal, South Korea and Sweden. ${ }^{2}$

Table 1 presents the levels of the Gini coefficient in the first year around or since 1980 for which we have data on this basis, and which year that was, figures for the latest available year (often 2013 in LIS), and the change between them. We see that the US and the UK had pronounced increases in inequality over the period from around 1980; these have been the focus of a great deal of research and commentary. Among other English-speaking countries, Australia and New Zealand also saw marked increases, while Canada had a smaller but still substantial increase, although Ireland did not. Japan also saw some increase in the Gini; with data for South Korea only from 2006, nothing can be said about the long-term evolution of inequality there. Among the traditionally low-inequality Nordic countries, Finland and especially Sweden saw pronounced increases in inequality. Norway had a more modest but still substantial rise, whereas for Denmark the Gini was little changed. For Iceland, only the period from 2004 is covered, during which inequality fell in the particularly severe financial and economic crisis affecting that country from 2008.

Among the 'continental' European countries, Belgium, Luxembourg, Germany and the Netherlands saw some increase in inequality, whereas for Austria there was little change and for France inequality appears to have fallen. For the southern European countries, Italy and Spain saw an increase in inequality overall, whereas for Portugal, where the data cover only from 2004, inequality was lower in 2013. This also appeared to be the case for Greece, though this masked the marked fall in the years up to the financial crisis and pronounced increase during it. For the formerly state socialist and low-inequality countries, the picture is mixed, with some seeing large increases from their initially low levels of inequality, though the fact that the initial year observed is well after the early-1990s transition for some countries complicates this comparison.

Overall, about two-thirds of the countries saw an increase in the Gini of at least 1 'Gini point' (i.e. at least 0.01 ) over the period covered for each. If we simply average the Gini levels across these countries in the first and in the last years for which we have an estimate in each case (despite the fact that the initial year and number of years covered varies across countries), that average goes up by almost 3 'Gini points'. However, the extent of variation across countries is very considerable: some countries saw little or no increase in inequality, while others saw modest rather than substantial increases, and still others saw really pronounced rises.As we have emphasized, the LIS and OECD databases often differ in how far back they allow one to go towards 1980. To see what happens if we are able to go back closer to 1980 for more countries, and assess whether different sources tell the same story, we can compare figures from the LIS and OECD databases and put them alongside ones from the Chartbook of Economic Inequality (Atkinson et al. 2017), which covers 12 of the countries included here, and figures for most of these countries from the database assembled by country experts as part of the Growing Inequalities' Impacts (GINI) collaborative research project from 1980 to 2010 (Nolan et al. 2014; Salverda et al. 2014). Table 2 provides a comparison of trends over time in the Gini across these four sources, covering the longest period each provides back to around 1980; we go up to 2007, just before the onset of the Crisis, which allows us to have a common end-point and highlight long-term trends rather than the effects of the recession.

income-distribution-database.htm, and Gasparini and Tornarolli (2015) provide a review.

${ }^{2}$ LIS data for Belgium go only as far as 2000, while OECD has data from 2004; we link these series to assess change over the entire period. See also Nolan et al., (2017) and Nolan, (2018b). 
Table 1: Gini Coefficient from 1980 (or nearest available year) to 2013 (or nearest available year), Equivalised Disposable Income

\begin{tabular}{|c|c|c|c|}
\hline Country & Gini in 1st year (year) & Gini in last year & Change in Gini \\
\hline Australia & $0.282(1981)$ & 0.334 & 0.052 \\
\hline Austria & $0.282(1994)$ & 0.281 & -0.001 \\
\hline Belgium & 0.228 (1985) & 0.262 & 0.034 \\
\hline Canada & $0.289(1980)$ & 0.324 & 0.035 \\
\hline Czech Republic & $0.206(1992)$ & 0.259 & 0.053 \\
\hline Denmark & 0.257 (1987) & 0.252 & -0.006 \\
\hline Estonia & $0.364(2000)$ & 0.354 & -0.010 \\
\hline Finland & 0.207 (1987) & 0.261 & 0.054 \\
\hline France & $0.319(1978)$ & 0.292 & -0.027 \\
\hline Germany & $0.266(1984)$ & 0.295 & 0.029 \\
\hline Greece & $0.352(1986)$ & 0.344 & -0.008 \\
\hline Hungary & 0.289 (1991) & 0.293 & 0.004 \\
\hline Iceland & 0.257 (2004) & 0.246 & -0.011 \\
\hline Ireland & $0.330(1987)$ & 0.296 & -0.034 \\
\hline Israel & $0.310(1986)$ & 0.373 & 0.063 \\
\hline Italy & $0.310(1986)$ & 0.332 & 0.022 \\
\hline Japan & $0.304(1985)$ & 0.330 & 0.026 \\
\hline Luxembourg & $0.236(1985)$ & 0.284 & 0.048 \\
\hline Netherlands & $0.263(1977)$ & 0.283 & 0.020 \\
\hline New Zealand & 0.271 (1985) & 0.333 & 0.062 \\
\hline Norway & $0.226(1979)$ & 0.253 & 0.027 \\
\hline Poland & $0.262(1992)$ & 0.322 & 0.060 \\
\hline Portugal & $0.382(2004)$ & 0.345 & -0.037 \\
\hline Slovak Republic & 0.189 (1992) & 0.270 & 0.081 \\
\hline Slovenia & 0.229 (1997) & 0.271 & 0.042 \\
\hline South Korea & $0.306(2006)$ & 0.302 & -0.004 \\
\hline Spain & $0.320(1980)$ & 0.346 & 0.025 \\
\hline Sweden & 0.198 (1983) & 0.281 & 0.083 \\
\hline Switzerland & $0.285(2000)$ & 0.296 & 0.011 \\
\hline United Kingdom & 0.267 (1979) & 0.334 & 0.067 \\
\hline United States & 0.312 (1979) & 0.383 & 0.071 \\
\hline Average & 0.277 & 0.304 & 0.027 \\
\hline
\end{tabular}

Notes: LIS except OECD for Canada, Greece, Japan, Netherlands, New Zealand, Portugal, South Korea and Sweden, and for Belgium from 2004 
One can see that differences between the sources in how inequality is seen to have changed arise most often where they cover different periods. For France, to give just one example, the LIS data we have used from 1979 show a decline in the Gini, whereas the OECD data begin in the mid1990 s and show a modest increase from that starting-point. There are however also some divergences between the sources even when they cover similar periods. For the UK, for example, the increase in inequality shown in LIS, which we have used here, is greater than in the OECD database for approximately the same period; it is however similar to the increase is seen in the Chartbook and GINI database. For Sweden the picture is less reassuring: the OECD database, which we have used here (because in that case LIS does not go beyond 2005), shows a much lower increase in inequality than either the Chartbook or the GINI database.

It is clear that the data source employed matters, so comparative studies relying on either the LIS or OECD databases, as most do, will not always be incorporating the same trends. While there are question-marks for certain countries, overall these figures show that about two-thirds of the countries having a significant increase in inequality from around 1980 up to just before the economic crisis, with an average increase of about 4 Gini points. However, while a simple summary along the lines of "Income inequality has increased in most rich countries since around 1980" is valid as far as it goes, this clearly risks obscuring major, consequential differences in country experiences. This also relates to the key point, as emphasised for example by Forster and Toth (2015), that increases in inequality have often occurred in discrete 'episodes' rather than in a consistent fashion over time - with the example of the UK, where most of the increase in the Gini was concentrated in the Thatcher period of the early/mid-1980s, being only one example. Understanding what has been happening to inequality in rich countries requires not only identifying the forces driving inequality up, but also explaining why their effects have varied so widely across the OECD, and indeed over time within countries.

The inequality data and measures we have employed so far refer to the entire distribution, but much of the recent discussion of inequality has focused on what is happening at the very top. Recentlyavailable estimates have shown striking increases in the share of total income going to the top 1\% since around 1980 in countries such as the UK and the US (see Acemoglu 2002; Atkinson and Piketty 2007; Piketty 2014). These figures are based on data from the administration of income taxes together with the national accounts, since surveys find it difficult to capture the top of the distribution well for a variety of reasons. We can look at trends in income shares at the very top of the income distribution for the sub-set of the OECD countries for which these estimates are available in the World Wealth and Income Database (see http://wid.world). These refer to the share of the top $1 \%$ in gross (before income tax and social insurance contributions) rather than disposable income, to the tax unit rather than the household, and are not equivalised. ${ }^{3}$

Table 3 shows that from 1980 to 2007, just before the global financial crisis struck, the share going to the top $1 \%$ went up in most of these countries, but by a great deal more in some than in others. On the basis of initial estimates, Atkinson and Piketty (2007) highlighted a contrast between the Englishspeaking versus continental European countries, with the former seen as having much larger increases. This contrast is not quite as stark with the estimates available now, though the scale of the increase is clearly greatest for the UK and the US, with Canada the next-largest. Strikingly,

${ }^{3}$ Estimates on a post-tax basis have been produced in separate studies for a few countries. 
Table 2: Change in Gini Coefficient by Country from Nearest Year to 1980 up to 2007, alternative data sources

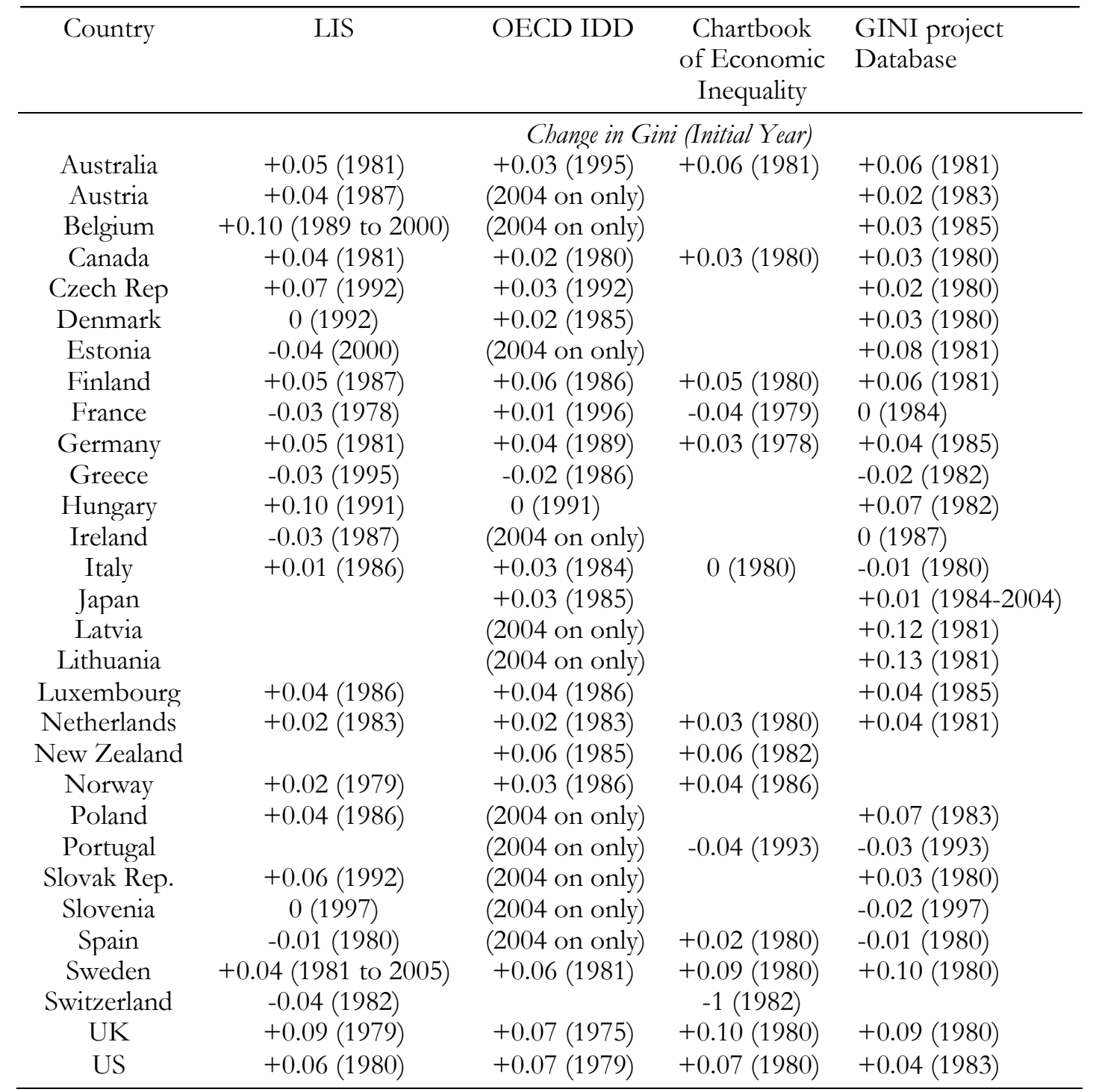

Source: LIS, OECD IDD, Chartbook of Economic Inequality, GINI Project

Database 
Table 3: Top 1\% Shares in Selected OECD Countries, 1980 Onwards

\begin{tabular}{crrccc}
\hline Country & 1980 & 2007 & $\begin{array}{c}\text { Change } \\
1980-2007\end{array}$ & Latest value & Latest year \\
& & & & \\
Australia & 4.61 & 9.09 & +4.48 & 9.10 & 2014 \\
Canada & 8.88 & 15.63 & +6.75 & 13.62 & 2010 \\
Denmark & 5.47 & 6.12 & +0.65 & 6.41 & 2010 \\
Finland & 4.32 & 8.26 & +3.94 & 7.46 & 2009 \\
France & 8.17 & 11.69 & +3.52 & 10.80 & 2014 \\
Germany & 10.72 & 14.04 & +3.32 & 12.98 & 2011 \\
Ireland & 6.65 & 11.64 & +4.99 & 10.50 & 2009 \\
Italy & 6.90 & 9.86 & +2.96 & 9.38 & 2009 \\
Japan & 8.36 & 11.35 & +2.99 & 10.44 & 2019 \\
Korea & 7.47 & 11.28 & +3.61 & 12.33 & 2012 \\
Netherlands & 5.85 & 7.57 & +1.72 & 6.33 & 2012 \\
New Zealand & 5.65 & 7.83 & +2.18 & 8.09 & 2014 \\
Norway & 4.60 & 8.54 & +3.94 & 7.80 & 2011 \\
Portugal & 4.32 & 9.77 & +5.45 & & \\
Spain & 7.63 & 11.24 & +3.61 & 8.58 & 2012 \\
Sweden & 4.13 & 9.95 & +5.82 & 8.73 & 2013 \\
Switzerland & 8.40 & 10.91 & +2.51 & 10.62 & 2010 \\
United Kingdom & 6.67 & 15.44 & +8.77 & 13.88 & 2014 \\
US & 11.05 & 19.87 & +8.82 & 20.20 & 2014 \\
\hline
\end{tabular}

Source: World Wealth and Income Database

Denmark is the only country where the top $1 \%$ share rose by less than 1 percentage point. Table 3 also includes the latest available estimates at time of writing, and these generally show either stability or some decline in the top $1 \%$ share occurred after the Crisis, with a marked fall in Canada, Spain and the UK. This reflects the impact of the economic and financial shock on profits, top executive reimbursement, and the financial sector in particular. It is noteworthy though that in the case of the US, although the share of the top $1 \%$ fell quite sharply at the onset of the Crisis, it was back to its pre-Crisis level by 2014. It is also worth noting that evidence for the US (such as Dew-Becker and Gordon 2005) and some other countries shows just how important an increase in the share going to the very top - the top $0.1 \%$ - has been, with inequality thus also rising within the top.

One of the elements underlying the distribution of income among households is the factor distribution, the aggregate share going to capital versus labour, and since this also features extensively in research on inequality it is worth briefly describing key trends. Recent decades witnessed a marked and prolonged decrease in the labour share, Figure 1 shows the evolution of the labour share for a group of 23 advanced economies (combined into a single measure using GDP as weights). The decline in the labour share is substantial: about 5 percentage points between 1991 and 2016.

Focusing on the rich countries, the decline in the labour share at country level is highly correlated with the increase in market income inequality among households. Figure 2 shows this relationship for a selection of 16 rich countries, between 1990 and 2015 (when possible), for which comparable data is available.

Consistent with the evidence on top $1 \%$ income shares presented earlier, the fall in the labour share 
Figure 1: Evolution of the labour share for 23 OECD countries

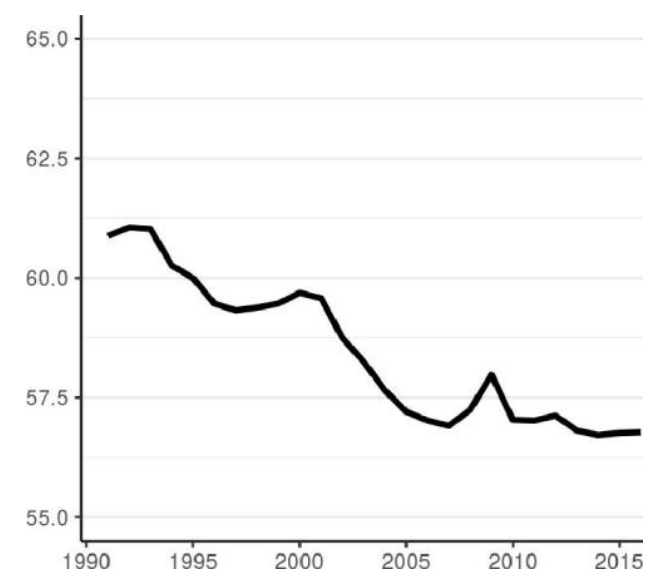

Notes: computed as the weighted average of individual countries' labour share, using GDP as weights. Countries are EU-15, plus Australia, Canada, Japan, Korea, New Zealand, Norway, Switzerland and United States. Source: Authors' elaboration based on Eurostat - AMECO database.

Figure 2: Changes in the labour share and in market income inequality in 16 OECD countries, 1990 to 2015

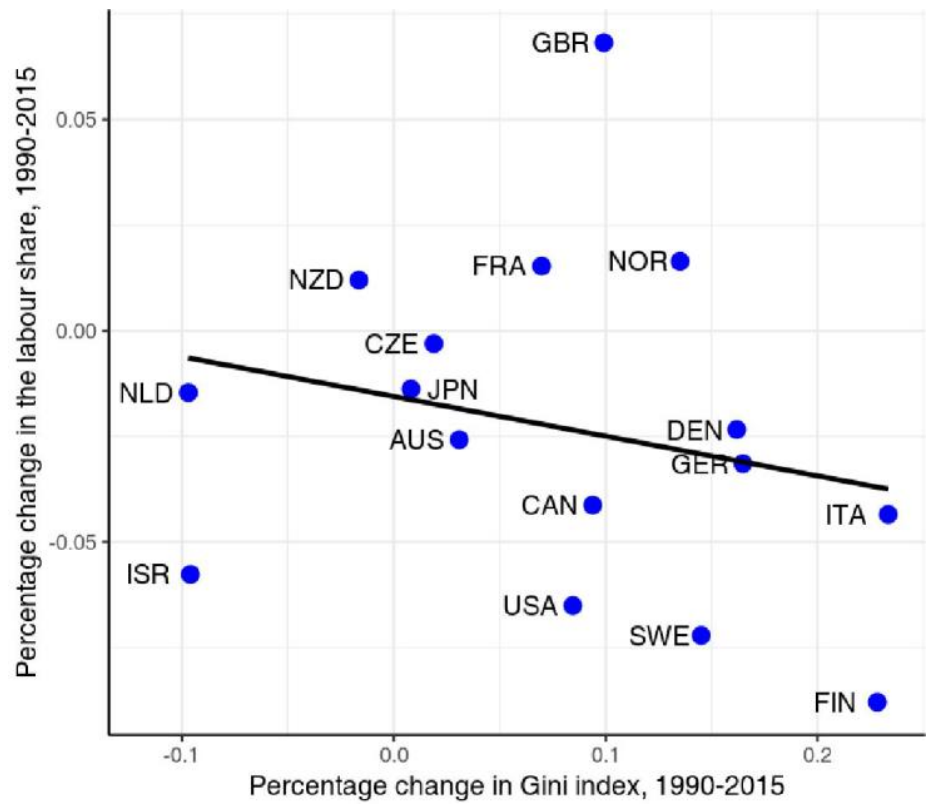

Notes: Countries include Australia, Canada, Czech Republic, Denmark, Finland, France, Germany, Israel, Italy, Japan, Netherlands, New Zealand, Norway, Sweden, United Kingdom, and United States. The period varies across countries, depending on data availability (average length is 21 years). The Gini coefficient is based on pre-tax and transfer income of the population aged 18 to 65 years. Source: Authors' elaboration based on OECD data. 
is even larger if one considers only the bottom $99 \%$ of workers (OECD 2012). For example, during the period 1990 and 2008, the decrease in the labour share in the United States doubles in size. The fall in the labour share would also have a greater impact on measures of inequality that go beyond current cash income - for example, when the value of non-cash services such as health and education and the undistributed profits of companies are attributed to households, as they are in the World Inequality Report 2018 (Alvaredo et al. 2018).

\section{Research on individual drivers of inequality}

Research across the social sciences has identified a very wide variety of forces driving inequality in rich countries upwards, ranging from globalisation to technological change, finance, market power in labour and product markets, labour market institutions and regulations, demographic and household structures, redistribution policies, and political processes and behaviours. The pathways involved are complex and inter-connected, and changes in inequality also potentially feedback to affect some of the drivers, but most of the research has focused on the effects of individual drivers along specific channels of transmission. This is the research surveyed here. Due to the major difficulties involved in taking into account all the feedbacks, especially when only macro variation on some of the drivers is often available, few attempts have been made at providing an integrated assessment of the relative importance of each driver, and their interaction. These are reviewed in Section 4.

\subsection{Globalisation}

Globalisation has many dimensions. Forster and Toth (2015) for example distinguish between (i) trade integration, (ii) offshoring and foreign direct investment (FDI), (iii) migration, (iv) technology transfers and (v) financial integration. At this stage we focus on trade, offshoring/FDI, and migration, returning to finance below. Perhaps the clearest evidence of the dramatic expansion of globalisation in the recent decades comes from data on the number of regional trade agreements (RTA) in force by year, presented in Panel (a) of Figure 3. Whereas in 1990 there were 19 RTA in force, twenty years later this number had risen tenfold. By the end of 2017, there were 285 active RTA. Whilst RTA represent the legal structure enabling greater trade, actual levels of trade have also increased sharply, as Panel b of Figure 3 reveals. ${ }^{4}$

Expanded opportunities for trade in inputs and outputs have translated into more intricate and globalised value chains, as firms reallocate production to low-cost countries, and then deliver the goods and services to the final consumers worldwide (WTO 2013). Producers can be either local firms, or foreign firms that off-shore part of their production capability, usually through foreign direct investment. The Stolper-Samuelson theorem postulates that a country's abundant production factors gain from openness while scarce factors lose; with capital and skilled labour relatively abundant in advanced economies, income inequality would be expected to increase there. However, since the 1990s many studies have pointed to limitations of the standard model and suggested a variety of different ways in which globalization may also affect income inequality, including via within-sector shifts in production and vertical specialization across countries. For instance, rising import competition may also induce investments in new technologies and accelerate technological

${ }^{4}$ For a comprehensive statistical analysis of the evolution of globalisation amid its multidimensional facet, see OECD (2010) 
Figure 3: Some indicators of globalisation

(a) Number of active regional trade agreements in the world

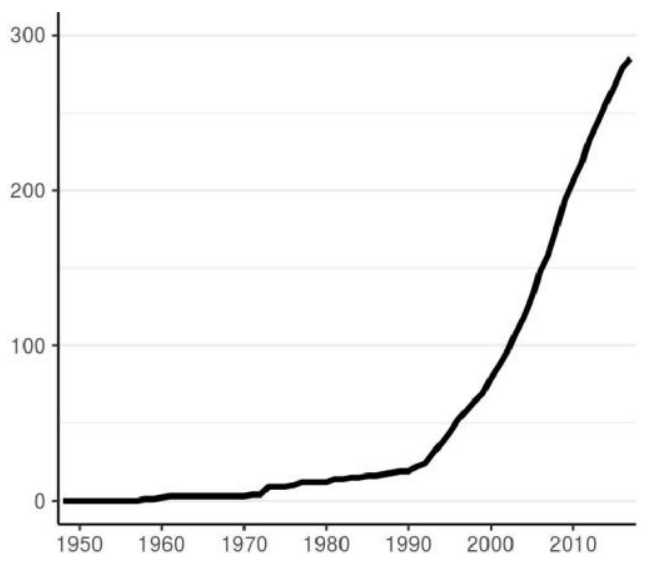

Source: Authors' elaboration based on World Trade Organization data (b) Sum of world's exports and imports over world's GDP

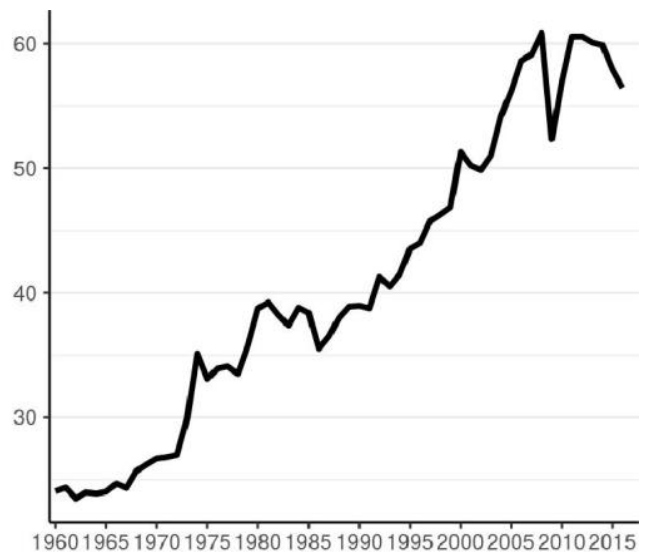

Source: Authors' elaboration based on World Bank data

shifts which decrease employment of relatively unskilled workers (Bloom, Draca and Van Reenen 2016). The opportunities from trade and offshoring may also make some firms more productive than others. In effect, it is a new stylised fact in the literature that high productivity firms self-select into exporting (see Greenaway and Kneller 2007 and Wagner 2007 for reviews of this literature). This is clear from the fact that exporting involves sunk costs, hence leading only the most profitable firms to export. Likewise, exporters' productivity usually increase after entering an export market, not the least because of "learning by exporting" (e.g. Atkin, Khandelwal and Osman 2017; Crespi, Criscuolo and Haskel 2008; De Loecker 2013; Girma, Greenaway and Kneller 2004).

Given these behavioural responses to increased export opportunities, it is natural to expect a greater role of between-firm wage differentials in explaining changes in inequality. This is what the literature has mostly found. Starting from the seminal paper by Abowd, Kramarz and Margolis (1999), a myriad of studies employing micro-data have attempted to decompose levels and changes in overall wage inequality in between-firm and within-firm components. Most of the evidence seems to point mainly to between-firm factors (like productivity) when explaining wage inequality across workers (e.g. Barth et al. 2014; Card, Heining and Kline 2013; Song et al. 2019). If better workers tend to match with better firms (positive assortative matching), then those firms will attract more productive workers and pay them higher wages, hence increasing inequality (Helpman 2016). Globalisation can also affect the outside options of firms and workers and hence their bargaining power, to which we return below. This between-firm component is also related to the rise of "superstar firms", to be explored later. Still, the within-firm factors might be present, particularly when it comes to CEO pay. Cuñat and Guadalupe (2009b) use a large sample of manufacturing firms in the US to show how greater foreign competition (resulting from lower trade barriers and enhanced globalisation) enhanced the sensitivity of pay to performance for highest-paid executives, and led to greater wage inequality within firms. Globalisation, and in particular the entry of China and India into the global trading system, opened up rich country manufacturing to intense competition from emerging economies 
with lower labour costs, while also fostering capital mobility across borders. As Bivens (2015) notes, the opening up of China and India to international trade was equivalent to the entrance of around a billion workers, for the most part unskilled, into international competition. He shows that those at the low end of the wage distribution in rich countries were initially most affected, as trade mainly involved cheap manufactured goods; in a second phase, increased competition in intermediary services affected workers more in the middle of the wage distribution, contributing to the "hollowing out" of that distribution. This increased competition among workers might be one of the factors driving down the labour share (and driving up the capital share), as workers' power in the bargaining of wages is lowered. In effect, a negative effect of several proxies for globalisation on the labour share has been documented in the literature (e.g. Harrison 2005; Jayadev 2007).

The link between globalization and income inequality has received a huge deal of attention in the literature since the early 1990s. It is beyond the scope of this section to outline this research, repeating what other recent reviews have done (e.g. see Harrison, McLaren and McMillan 2011; Helpman 2016; Kurokawa 2014). We just highlights some key results. In particular, one of the main challenges the study of globalisation faces is disentangling its effect on inequality from that of technological change (analysed later in Section 3.2); the difficulties in doing so are made clear in our review of the findings of recent multivariate empirical studies in Section 4. To give a flavour of these findings at this point, though, the broad thrust of recent empirical studies is generally to assign a limited role to globalisation in explaining increases in inequality in earnings or household incomes in the rich countries. For instance, Helpman's (2016) review of the literature - considering both developed and developing countries and micro- and country-level studies - concludes that trade did increase overall wage inequality, but can only explain a small portion of the overall increase in inequality observed in rich and poor countries. Focusing on inequality at the national level may however miss a critically important - if more localised - impact of globalisation on workers. In their widely cited paper on the impact of trade with China on different industries and plants, local labour markets and individual workers in the U.S., Autor, Dorn and Hanson (2016) find that adjustment in local labour markets is remarkably slow, wages and labour force participation rates remaining depressed and unemployment rates remaining elevated for at least a full decade after the 'China shock', exposed workers experience greater job churning and reduced lifetime income. ${ }^{5}$ However, the large and long-lasting adverse effects on local economies detected by Autor and co-authors are still consistent with the general assertion that trade plays only a minor role in the shrinking size of U.S. manufacturing. Overall, Autor et al. find that the China shock is responsible for the loss of 985,000 jobs in manufacturing between 1999 and 2011. As Paul Krugman put it, "[t]hat's less than a fifth of the absolute loss of manufacturing jobs over that period, and a quite small share of the long-term manufacturing decline." (Krugman 2016). Ebenstein et al. (2014) use a rich dataset of US workers, following their occupational changes. They find that occupational switching due to increased trade (perhaps due to firms reallocating part of production abroad) led to significant real wage reductions in workers. Hakobyan and McLaren (2016) derive an analogous picture when studying the consequences of Mexican competition through NAFTA on US workers. Although they find little effect on the average worker, blue-collar workers in most "NAFTA-vulnerable" locations did suffer considerable wage losses, effect which intensifies in "NAFTA-vulnerable" industries. Similar local disparities are documented for Germany by Dauth, Findeisen and Suedekum (2014), where job losses and lower wages occurred in regions facing import-competition from China, whereas the opposite occurred in

${ }^{5}$ In related work, Autor et al. (2016) have shown that these disparities have had political consequences too in terms of political polarisation of voters. 
export-intensive regions. For further examples with more or less similar results see Balsvik, Jensen and Salvanes (2015) for Norway, Crozet and Orefice (2017) for France, Foliano and Riley (2017) for the United Kingdom, and Nilsson Hakkala and Huttunen (2016) for Finland.

The effect of globalisation on inequality is sometimes explored through the narrower channel of offshoring. ${ }^{6}$ There is a very large literature on the effects of offshoring on labour markets which we are not able to review here, and which conclusion vary depending on the focus (sector, period, country, data, etc) (for surveys, see Crino 2009 and Hummels, Munch and Xiang 2016). Yet, if one common message emerges from this research, it is that offshoring has in many industries and countries induced important occupational changes (like job polarisation), sometimes (but not always) leading to greater wage inequality. This message resonates with the common theme of previous results, namely that globalisation, albeit having a minor effect on national level inequality among advanced economies, has led to substantial heterogeneity across industries, geographies, firms and individuals in terms of the benefits and costs of greater globalisation. As seen, these effects are routed through different channels like import-competition and offshoring.

Another area of research that has gained recent empirical traction relates to the effect of globalisation on inequality through tax competition and tax avoidance using micro-data (e.g. Alstadsæter, Johannesen and Zucman 2017; TØrslØv, Wier and Zucman 2018; Wright and Zucman 2018). Since capital income mostly accrues to richer individuals, (capital) income tax competition, through inducing lower taxation, disproportionally benefits the rich. Globalisation has also facilitated tax shifting and tax evasion by richer individuals and firms (with capital income from firm ownership accruing mostly to the rich). These two imply higher top income shares because of globalisation.

Migration (another aspect of globalisation) also has important effects on inequality. Migratory flows generally involve people from low-income countries going to work in high-income countries. This lowers global inequality, as (i) migrants usually improve their own economic situation, and (ii) send remittances home, hence improving the economic situation of their relatives as well. On the other hand, migration tends to increase inequality at a national level, both in the origin country (migrants typically come from the most educated, young and healthy segments of the population) and in the destination country. The latter occurs because migrants have typically access to low-paying jobs; moreover, the increased abundance of cheap labour might put a downward pressure on wages of natives involved in the same tasks. However, this effect is shown to be small (see in particular Card 2009, and the review of the literature in Kierzenkowski and Koske 2012), while the effect higher up in the wage distribution is likely to be zero (Manacorda, Manning and Wadsworth 2012) or even slightly positive (Dustmann, Frattini and Preston 2013; Ottaviano and Peri 2012). At the very top of the earnings distribution, however, greater international mobility among top managers may have played some role in the spread from the US to other rich countries of widening gaps between CEO pay and that of the typical worker.

\subsection{Technological change}

In the economic growth literature started by Solow (1957), technological progress was understood primarily as driving total factor productivity, thereby leading to improvements in the productivity

\footnotetext{
${ }^{6}$ It is reasonable to argue that offshoring itself, whilst being a specific form of trade and thus related to globalisation, it is also facilitated by technological innovations (e.g. ICT), particularly in services. This is, even if no regulatory changes like a RTA come into force, ICT innovations might still induce offshoring. Thus, a very sharp distinction between globalisation and technological change on this respect is surely artificial.
} 
and wages of all workers. Early empirical and theoretical contributions however, including Griliches (1969) and Tinbergen (1975), already highlighted the potentially biased nature of technological change, in particular because of the strong complementarity observed between capital and skilled labour. Since then, a large literature has explored this and other biases associated with technical change, including topics like skill-biased technical change, endogenous technical change, task-biased technical change, and recent developments on automation, robots, AI, and digital technologies. It is unnecessary here to repeat what excellent reviews on the topic have already done (e.g see Acemoglu 2002; Acemoglu and Autor 2011; Chusseau, Dumont and Hellier 2008). Instead, we will focus on key aspects of the debate.

A robust conclusion from this literature is that technology in itself tends to yield higher inequality among workers (particularly since the beginning of the 20th century), but the final outcome depends on how other variables (and agents) respond to the modified incentives and conditions. Additionally, technology in itself is not an exogenous process but it responds to incentives (e.g. profitability). These two factors together mean higher inequality is not an unconditional outcome of technological progress, but one that is shaped through institutions and policies.

One clear example of the above is skill-biased technological change (SBTC), defined as technological change causing an increase in the relative productivity of skilled labour with respect to that of unskilled labour. Goldin and Katz (2008) show that SBTC did not yield higher inequality in the US between 1915 and 1980, but has done so more recently. This is because the supply of skilled labour was not able to keep pace with the increased demand - Tinbergen (1975) famous "race between technology and education", thereby raising the skill premium. Policies (in this case, education) matter.

While SBTC has been widely explored in the literature, some authors have highlighted its inadequacy to explain more granular phenomena like rising top income shares (and how this has varied across countries) and recent trends on job polarisation (e.g. Acemoglu and Autor 2011; Atkinson, Piketty and Saez 2011; Dew-Becker and Gordon 2005). The latter refers to the fall in employment in middle-skill intensive occupations, together with an increase in employment in low-skill and high-skill intensive occupations. It has been documented for many advanced economies, at the country and industry level (e.g. Acemoglu and Autor 2011 for US; Goos, Manning and Salomons 2014 for Europe). The alternative explanation for job polarisation is called task-biased technical change (TBTC), as it focuses on tasks rather than skills. We can more easily think of this as a two layered setting where workers sometimes together with capital - produce tasks, which are then combined to produce a final good. In TBTC, some tasks are becoming relatively more productive in terms of their contribution to the final good than others. The standard example is routine tasks in occupations like office clerks (usually considered middle-skilled, at least in terms of their position in the wage distribution). This is, less workers (or working hours) are needed to produce the same "amount" of task. A reduction in the price of the capital used for such tasks can also contribute to the demand for such labour (as Autor and Dorn 2013 theorise the final effect on the demand for employment in routine tasks depends on the parameters of the model). This polarisation of the labour market can also lead to wage polarisation (e.g. Acemoglu and Autor 2011 for US; Borrs and Knauth 2016 for Germany). Technological change, and in particular the advent of ICT, clearly interacts with globalisation in many different dimensions. Technological advances meant that global supply chains could be organised in such a way that jobs formerly embedded in the rich countries could be offshored much more easily, taking advantage of reduced trade barriers. As offshoring 
tend to be intensive in routine tasks, it has been empirically linked to job polarisation (e.g. Goos, Manning and Salomons 2014).

Globalisation itself can foster technological advancement. For instance, Bloom, Draca and Van Reenen (2016) use firm-level data for twelve European countries to show that innovation, TFP, R\&D and related variables increase for firms more exposed to Chinese imports. Similarly, Koren and Csillag (2017) use Hungarian employer-employee data to show how the import of machines propagates skill-biased technical change. Using data on mergers and acquisitions for the US, Ma, Ouimet and Simintzi (2016) find evidence consistent with higher SBTC and TBTC facilitated by such events, which are themselves more attractive as globalisation increases.

As well as advantaging the highly skilled in general, the interaction of technological change and globalisation has particularly benefited so-called 'superstars', both at the individual and firm level. What may well be small difference in talent are magnified in terms of earnings by the ability to dominate an increasingly global market. In terms of individuals, the canonical examples are actors, musicians and sports stars. Thanks to technology, what was previously a performance for only a limited audience can now be broadcast to millions. At the same time, information about top performers is more widely available, leading to tastes homogenisation through network effects. Amid this context, a handful of performers earn huge returns. The rise of 'superstar' CEOs has also been linked to technological change. For instance, Garicano and Rossi-Hansberg (2006) construct a model of a knowledge-based economy where organisational hierarchies based on skill arise naturally in equilibrium, such that high skill individuals focusing on problem-solving, knowledge intensive tasks are in the top of the hierarchy (i.e. as CEO). They then show that fall in the costs of communication between agents and of accessing knowledge benefit disproportionally those individuals with a comparative advantage on knowledge intensive tasks, thereby leading to wage inequality between those at the top and the rest of the workers. Gabaix et al. (2016) also shows theoretically how this increase in the "scope of CEO talent" is consistent with rapid increases in top income inequality, as observed in the US. Using executive compensation data from S\&P firms, Keller and Olney (2018) find more globalised firms (in terms of trade and FDI flows) pay more to top executives, ceteris paribus.

In terms of 'superstar' firms (a concept originally developed by Rosen 1981), Manyika et al. (2018) provides a characterisation of the world's 5,750 most profitable firms (both public and private), showing how the top $10 \%$ of these differ from the rest. ${ }^{7}$ In particular, top firms are not only more profitable but also more intensive in intangible capital, invest more in $R \& D$, and are much more global in terms of trade and FDI, highlighting the potential role of technological change and globalisation in their success. Moreover, the authors show that the gap between 'superstar' firms and the rest in terms of several performance indicators has also widened between 1995-7 and 2014-6. Autor et al. (2017) provide some empirical confirmation to this 'superstar firm story when explaining the fall in the labour share. Using firm level data for the US and other advanced economies, they find as negative relationship between industry concentration (in terms of sales) and the labour share at the industry level. Furthermore, they find that both technical change (measured as either patent intensity or TFP) and trade (measured as exposure to Chinese imports) are positively correlated with industry-level market concentration and negatively related with the labour share. A recent survey by Reenen (2018) also concurs with the above in that 'superstar'

\footnotetext{
${ }^{7}$ Profitability is measured as the excess return on invested capital with respect to the weighted average cost of capital, multiplied by the size of invested capital. It is thus a combination of size and economic "rents".
} 
firms are a feature of an economy increasingly dominated by "winner take most/all" markets, itself a product of globalisation and technological change.

From another perspective, a recent literature has emerged looking at the consequences of increased automation of jobs, especially but not exclusively due to industrial robots. Using (aggregate) panel data for 17 developed countries, Graetz and Michaels (2018) find no effect of the use of robots on overall employment, but a negative one on low skilled workers' employment. The same result emerges from a study by Dauth et al. (2017) of German workers, using employer-employee linked data. In particular, the authors find no overall effect of robots on employment, but a negative effect on manufacturing employment, compensated by an increase in employment in services. Wage-wise, high-skilled workers benefit from robots whereas the negative effect is felt mostly by low and middle skill workers in manufacturing. Focusing on US local labour markets, Acemoglu and Restrepo (2017) also find a negative effect of local industries' exposure to robots on both employment and wages, effect which is more pronounced in manufacturing and in low skill workers.

All the studies mentioned so far focuses on certain types of biased technical change (e.g. in terms of skills, tasks, automation). A complementary approach is to focus on neutral technical change, namely on TFP. For instance, Hornbeck and Moretti (2018) use microdata from the US to study the effect of TFP growth at the city level on wages and purchasing power. When considering direct and indirect effects together (i.e. those of local and non-local TFP growth on local workers) they find an overall positive effect of TFP on purchasing power of high and low skill workers, with no effect on inequality. This relatively different conclusion with respect to previously mentioned research shows more analysis is needed to assessing the overall effect of different forms of technical change on inequality. Finally, the role of public policy (specially beyond education) mediating technical change consequences on society is also widely under-researched.

\subsection{Finance, Monetary Policy, Macroeconomic Cycles and Shocks}

The expansion in the role of finance over recent decades contributed directly to the growth in top incomes, with a substantial proportion of top earners working in that sector. The way finance developed also appears to have increased inequality in a variety of less obvious but very important ways (Tridico 2018). Financialisation loosely refers to "the increasing role of financial motives, financial markets, financial actors and financial institutions in the operation of the domestic and international economies" (Epstein 2005). Recent decades have seen abuses by financial institutions of monopoly power in credit and debit cards, predatory and discriminatory lending, and excessive risk-taking facilitated by de-regulation, which played a major role in the build-up of the bubble that led to the 2008 financial crisis. Changing financial norms, new financial instruments, deterioration of creditworthiness standards, and securitisation of mortgage debt generated increasing debt-income ratios for private households and increasing financial fragility for the economy as a whole (Hein 2015). Governments then socialised the losses of the banking system at taxpayers' expense (Stiglitz 2012). This socialization had a direct effect of reducing income and capital losses at the top, and an indirect effect of curbing social expenditures thanks to the austerity policies implemented in the face of the increased debt to GDP ratios.

The ways in which financialisation has served to increase income inequality may also operate through a number of other channels. The first involves the appropriation, by the finance industry, of a larger share of national income and profits. In many advanced countries the size of the financial sector as a 
share of GDP, which has been constantly growing since the end of WWII, accelerated in the run-up to the crisis: in the ten years between 1995 and 2005 the financial sector grew by $12 \%$ in Germany, $9 \%$ in Italy, 29\% in Japan, and 20\% in the U.K. (computed from OECD National Accounts data). At the same time, the financial sector managed to seize a disproportionate share of all the profits: a record high of $40 \%$ in the US at the onset of the crisis. Another channel involves the concentration of the financial sector on activities that provide little value added, or are even detrimental to the economy as a whole. In both the US and Europe, the unit costs of financial services have increased since the 1960s, despite advances in ICT and despite changes in the organization of the finance industry (Bazot 2018; Philippon 2015). Strikingly, the growth in financial intermediation appears to have a negative correlation with productivity growth (Cecchetti and Kharroubi 2015). A further channel is by providing an incentive for short-termism, so corporations are judged not by long-run growth prospects but by the immediate return to shareholders (Gutierrez and Philippon 2016). For the United States, borrowing has become more volatile: this reflects an increased concern for immediate profit opportunities, both on the demand side (companies) and on the supply side (the financial sector). Since the early 2000s, cash flow has been on the rise, investment has declined, while pay-outs to shareholders have increased (Mason 2015). Finally, the hostile takeovers, mergers and acquisitions made possible by the availability of credit may increase industrial concentration and mark-ups (Blonigen and Pierce 2016).

Another effect of the increased importance of finance is linked to the inequality of access to the financial markets. To start with, capital income and financial returns are typically taxed less than labour income. However, less well-off individuals are generally cut off from those returns. Moreover, financial returns have been shown to positively correlated with wealth (e.g. Fagereng et al. 2018), even if it is not clear whether this correlation has increased over time.

Dunhaupt (2017) analysed the role of financialisation in explaining the decline in the labour share in 13 OECD countries since the early 1980s. Her country-level analysis suggests an overall negative effect passing through: (i) a reduction in workers' bargaining power originated by increased shareholder value orientation and increased short-termism in management practices; (ii) an increase in overhead obligations in the form of interest and dividend payments, and management compensation; (iii) a shift in the sectoral composition of the economy from the public sector and the non-financial corporate sector with high labour income shares towards the financial corporate sector with a lower labour income share. These factors caused mark-ups to grow, with a corresponding decline in the labour share. Furthermore, attempts to reform the financial sector after the crisis may paradoxically have led to an increase in mark-ups in the financial sector itself, encouraging and in some case forcing banks to merge, so that concentration of market power there is even greater than before the crisis (Stiglitz 2015).

Several studies have linked the financial deregulation of the 1980's to increases in inequality (particularly considering that finance is the highest paying industry in many developed countries, e.g. Boustanifar, Grant and Reshef 2018). Tanndal and Waldenstrom (2018) use micro-data to connect the 'Big Bang' of 1986 (UK) and 1997-9 (Japan) with the observed higher top income shares. Philippon and Reshef (2012) also use micro-data to suggests deregulation in the US (particularly the relaxing and later repeal of the Glass-Steagall Act) increased significantly the premium paid in finance, even after controlling for education. Last but not least, using macro-data for 15 developed countries between 1970 and 2005, Boustanifar, Grant and Reshef (2018) also find 
financial deregulation to be the most important driver of the rapid increase in wages on finance relative to other sectors. They also find that the effect is larger in less competitive financial sectors, in more flexible labour markets, and where "non-traditional" banking (versus loan-based banking) is more developed. While regulation of the financial sector is one key tool in the armoury of governments with major implications for inequality, another is monetary policy. The channels by which both orthodox and unconventional monetary policy can affect inequality are varied, push in contradictory directions, and might change over the horizon under consideration (Galli and Hoeven 2001). One of the long-standing recognised channels is inflation. As Piketty (2014) puts it, "the redistributions induced by inflation are always complex, multidimensional, and largely unpredictable and uncontrollable" (p. 453). Recent research has identified a U-shaped relationship between inflation and overall income inequality (Galli and Hoeven 2001; Monnin 2014). As inflation goes up from low initial levels, inequality decreases due to redistribution from debtors to creditors, and to the fact that a more accommodating monetary policy leaves more room for wage increases. For higher levels of inflation however, lower earners are hit harder by the cost of inflation, and inequality starts rising again. Following high inflation in the 1970s and 1980s, the move by central banks towards inflation targeting may well have served to suppress real wage growth. In particular, in the low-inflation 'post-Volcker' world increases in wages are being used as predictors of future price increases, leading central banks to push on the brakes of the economy, tightening monetary policy and pushing up unemployment, even before inflation materialises.

More recently, the literature has focused on the role of low interest rates on the price (and therefore on the return) of financial assets. For example, recent unconventional monetary policies aimed at lowering long-term interest rates means a boost in the valuation of these assets (as the rate at which future income is discounted falls), which is inequality increasing. Domanski, Scatigna and Zabai (2016) explain part of the rise in wealth inequality between 2003 and 2015 in 6 developed countries based on such mechanism. On the contrary, another study by O'Farrell, Rawdanowicz and Inaba (2016), using a different set of developed countries and focusing solely in the 2007-2010 period, find a rather insignificant effect of monetary policy on both income and wealth inequality. Recent studies using micro-data tend to reinforce the connection between expansionary monetary policy and higher inequality. Coibion et al. (2017) use regression analysis with quarterly US data between 1980 and 2008 finding a negative but small effect of monetary policy shocks on income (and expenditures and consumption) inequality. Using quarterly data for more than four decades, Mumtaz and Theophilopoulou (2017) also find such a negative effect of monetary policy shocks in both consumption and expenditures for the case of the UK. All in all, it is evident that the literature has not settled the issue, and that more research is needed in the topic. ${ }^{8}$

Macroeconomic cycles, and especially major macroeconomic shocks such as the Great Recession from 2007/08 onwards, may also be important influences on income inequality - and financialisation may have played a significant role in that recession (e.g. Galbraith 2012). However, as Jenkins et al. (2013) pointed out in considering the Great Recession, neither standard analytical frameworks nor empirical studies of previous recessions provide clear cut conclusions about the distributional impacts of major recessions; that impact works through a wide variety of channels, changing the

\footnotetext{
${ }^{8}$ Bivens (2015) makes the relevant point that, even if expansionary monetary policy increases inequality, the proper counterfactual used to judge such increase is one where the central banks do not intervene in the economy (e.g. during the recent financial crisis), which could end up being one of worse economic conditions, higher unemployment and a deeper recession, in which inequality would well end up being worse than the one observed with the expansionary monetary policy.
} 
prevalence of receipt of particular types of income and the distribution of that income among recipients. Their empirical investigation of the impact of the 2007/08 crisis indeed showed that its initial distributional effects varied widely across rich countries, reflecting not only differences between them in the nature of the macroeconomic downturn itself, but also variation in the manner in which taxes and transfers cushioned household net incomes from the full consequences of reductions in market incomes. In a similar vein, a comprehensive analysis of the historical relationship between economic crisis and income inequality by Atkinson and Morelli (2011) with country-level data concludes that there is no hard and fast pattern, crises differ greatly from each other in their causes and outcomes in terms of inequality. The impact of the Great Recession in increasing inequality was indeed pronounced in certain rich countries, with Greece the most dramatic case in point, but the effects were generally much more modest.

This reflects the extent to which incomes towards the top as well as in the lower half are often affected by cycles and shocks, including in particular their finance-related elements. Parker and Vissing-Jorgensen (2009) for example drew attention to the fact that in the US the income (especially the wage income) of rich households had come to be more exposed to aggregate fluctuations than the bottom 80\%. Also for the US, Guvenen, Kaplan and Song (2014) find that individuals in the top $1 \%$ of the earnings distribution are slightly more cyclical than the population average, but this is much more pronounced for top earners in finance, insurance, and real estate and in construction. In a similar vein, an analysis by Morelli (2018) of major systemic banking crises since the beginning of the twentieth century in the US finds that these reduce income concentration within the top decile, with the richest income group losing ground, but this may not last long. The US analysis by Smeeding and Thompson (2013) and Almeida (2016) also highlight the crucial role played by the redistributive tax and transfers system in limiting the increase in income inequality in the immediate aftermath of the crisis, though then becoming weaker; we return to the centrality of redistribution in Section 3.7 below.

\subsection{Labour Market Institutions and Market Power}

In a neoclassical context, a perfectly competitive labour market means firms and workers have no direct influence on real wages. However, in the real world, firms do enjoy certain degree of monopsonistic market power. This can arise from (i) employer collusion, (ii) employer use of noncompete agreements, (iii) "job lock" mechanisms, in particular employer provided health insurance schemes, (iv) regulatory barriers, (v) market concentration, and (vi) other labour market frictions such as search costs arising from limited information, application costs, and barriers to workers' mobility due to housing costs or family constraints (CEA 2016).

Similarly, workers exert some counterbalancing power through labour market institutions like unions (which could be firm-specific like in the US or industry wide like in Germany). Ultimately, wages (and therefore the share of profits going to labour and capital) are the outcome of a bargaining process. In practice, the existence of monopsony power implies firms face a positively sloped labour supply, such that they can lower offered wages without losing all their workers. The slope of this supply depends on the relative power of firms and workers, and the institutional setting upon which this bargaining occurs.

Measuring monopsony power is not straightforward. Theoretically speaking, it requires a direct estimate of the elasticity of supply faced by firms. Importantly, this elasticity might be firm-specific, 
which means the natural estimation framework is at the individual firm level. Empirically, the challenge is in the correct identification of movements along the supply curve of the firm, without confounding such movements with more general equilibrium forces affecting the supply of the firm. As Manning (2011) argues, what is needed for correct identification of firm-level elasticities are instruments that "affects the demand curve for that firm but has negligible impact on the labour market as a whole" (p. 1006). In light of the status of this literature, high quality instruments of this kind seem hard to find. For a comprehensive survey on the theory and empirics of imperfect competition in the labour market, see Manning (2011).

Perhaps the most natural estimation framework is one where data on a single firm is used. Recent examples include Depew and Sorensen (2013) for two US-based companies (Ford Motor Company and A.M. Byers) and Ransom and Oaxaca (2010) for a "regional grocery retailer" in the US. ${ }^{9}$ The availability of such specific data is however scarce. Additionally, if one is interested in a large number of firms over several years - as in our case - this approach is unhelpful.

More broad firm level studies of monopsony focus instead on particular occupations like nurses (Staiger, Spetz and Phibbs 2010) or teachers (Falch 2010, 2011; Ransom and Sims 2010), or on a well-defined type of worker like low-wage workers in restaurants (Dube, Lester and Reich 2010) or undocumented workers in Georgia, US (Hotchkiss, Quispe-agnoli and Mandelman 2012). In these and related studies, identification is attempted through the exploit of natural or quasi-experiments arising from policy changes, via policy differences across contiguous local labour markets, or using very rich data in relatively homogeneous labour market environments. This approach to estimating elasticities is also interesting as it relates to the bargaining power of a particular profession in relation to their employers. However, most of firms employ an occupational mix, rendering such studies for our purposes - not very informative. Additionally, most of these estimates focus on a particular geographical area (again, for identification purposes). ${ }^{10}$

A novel approach to estimate firm-level elasticities of supply is just emerging, based on the increasing availability of employee-employee linked data, which covers a wide range of sectors and workers. This data is particularly helpful in allowing researchers to distinguish between firm and worker unobserved heterogeneity, removing many potential confounders. Papers using this approach include Barth and Dale-Olsen (2009) for Norway; Felix and Portugal (2017) and Garcia (2015) for Portugal; Hirsch, Schank and Schnabel (2010) for Germany; and Douglas (2016) and Webber (2015) for the US. Of the above, the most relevant for our purposes are Felix and Portugal (2017) and Webber (2015), who estimate the (long-run) distribution of firm labour supply elasticities, finding a significant degree of heterogeneity. ${ }^{11}$ These seem to be the first attempts in the literature to estimate such distribution. Still, the analysis in these and every other paper cited fall short in studying changes in such elasticities. This is clearly where the frontier of this literature stands at the moment, meaning we will soon be able - for the very first time, it seems - to confidently answer the question "has monopsony power increased?"12 Beside this, the key lesson from this literature,

${ }^{9}$ Howes (2005) and Reich, Hall and Jacobs (2005) study the effect on employment and wages of the introduction of a living wage in San Francisco. Their data comes from workers at the In-Home Supportive Services (a public provider of homecare) and the San Francisco Airport, respectively. Albeit they are not interested in the elasticity of supply, their results allow for such calculation. For details, see Table 6 in Manning (2011).

${ }^{10}$ Another source of imperfect estimates of monopsony power comes from studies of the average elasticity of supply of workers using household survey data, sometimes perform at the regional and country level (e.g. Bargain, Orsini and Peichl 2014, who provide a comparative analysis for 18 developed countries). Even if identification of elasticities of supply is achieved, these estimates hardly represent firm level elasticities.

${ }^{11}$ For the charts, see Figure 4 and Figure 2 respectively.

${ }^{12}$ Depew and Sorensen (2013), in their study of labour supply elasticity of two US firms, do measure the changes in 
as also concluded by Manning (2011), is that there is considerable extent of monopsony power in labour markets, power which is heterogeneous in many dimensions (including gender, e.g. Douglas 2016).

Regarding the effect of monopsony power on inequality, Felix and Portugal (2017) and Webber (2015) are again the key references. Both find a statistical and economically significant effect of market power on wages. Webber finds this effect to be heterogeneous across workers. In particular, the effect is larger the lower the wage of the worker, with no effect of market power on high wage workers. Using counterfactual analysis, Webber further estimates that "a one standard deviation increase of the labour supply elasticity facing each firm would decrease the variance of earnings distribution by 9\%." (p. 124) This is, to the best of our knowledge, the most direct test of labour market power on wage inequality available in the literature.

The analysis of labour market power so far has focused on direct estimates of the elasticity of labour supply. An alternative approach is to look at proxies of market power, or variables which are known or expected to influence market power - a "reduced form" perspective. A survey study by the US Council of Economic Advisors (CEA 2016) provides ample evidence that these sources of monopsony power have increased in importance in the US in recent decades. This includes more suits against employers for entering into no-poaching agreements in violation of the antitrust laws, an increasing share of the U.S. labour force covered by non-compete agreements (18\% in 2016), rising market concentration (more on this in the next section), increased prevalence of occupational licensing requirements (from 5\% of the workforce in 1950 to $25 \%$ in 2008), decline of unions (the share of workers represented by unions is down to $12 \%$ from about $25 \%$ in 1980), and declining geographic mobility (Molloy, Smith and Wozniak 2014). Declining job transition rates in the US have also been documented by Davis and Haltiwanger (2014). Meanwhile, Benmelech, Bergman and Kim (2018) measure monopsony power in terms of an employment-based Herfindahl-Hirschman index of firms in the US local labour markets, showing this has increased between 1977-1981 and 2002-2009, their period of study. Azar, Marinescu and Steinbaum (2017) follow a similar approach using online job vacancies from a US-based website, finding that higher market concentration in vacancies is associated with lower offered wages.

While not all of these developments have been observed across other rich countries, the decline in union membership certainly has. As Figure 4 shows, union membership across the OECD has declined from about $35 \%$ of wage and salary earners in the late 1970 s to about $15 \%$, reflecting a shift in the sectoral composition of the economy in favour of sectors that were less unionised as well as falling union membership within sectors. Manufacturing declined in most countries, while the service sector, characterised by weaker unions, increased its share of employment almost everywhere.

It is an established empirical fact that unions tend to boost wages for their members, and particularly for lower skilled workers (e.g. Card 1996). A novel analysis on this respect is Farber et al. (2018), who build an 80 years long database of union membership from US public opinion polls, showing that (i) the premium of belonging to a union has been roughly constant over the period, and (ii) greater union membership from low-skill workers vis-a-vis high-skill workers compresses the skill premium. Given these results, it is unsurprising then that a fall in unionisation increases both the capital-labour divide and the skill premium. Evidence of the former is presented by Kristal

such elasticity over time. However, their sample period is 1919 to 1940 , and is therefore mainly of historical interest. 
Figure 4: Evolution of trade union density in OECD countries

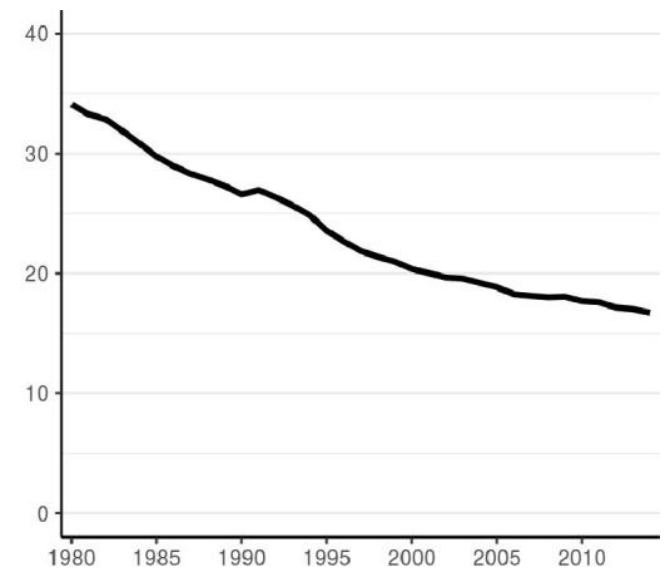

Source: Authors' elaboration based on OECD data

(2010), who studies country-level data for 16 OECD countries over the period 1961-2005. The author finds that changes in workers' bargaining power (particularly in terms of unionisation rates and strikes volume) explain most of the changes in the labour income share over the period. This holds both for the rise in the labour share observed in the 1960's and 1970's and the subsequent fall from the 1980's onwards. Similar effects of lower union density on the wage share is found by Guschanski and Onaran (2017), for 14 OECD countries, between 1970 and 2014. Relatedly, OECD (2011) documents how a decline in employment protection and the weakening of the system of labour relations contributed to a shift bargaining power away from workers and towards firms, and is widely seen to have played an important role in increasing earnings dispersion, a shift from labour to capital, and rising income inequality. Labour market regulations, the system of labour relations, and prevailing social norms also influence the relative bargaining power of firms and workers - the perception of what is fair and what is not underpins the functioning of the labour market as a social institution (Solow 1990). This has undergone deep changes over recent decades, with structural reforms aimed at increasing labour market flexibility became a dominant theme in many countries, most notably the European Union.

During the industrial age that lasted until the oil shocks of the 1970s, most European countries had put in place strict job security regulation. Even if union membership started to decline in the mid 1970s and some large European countries (France, Spain and, to a certain extent, Germany) had already started introducing flexibility into their labour markets in the 1980s through deregulation of fixed-term contracts, it is only at the beginning of the 1990s, with the influential OECD Jobs Study (1994), that structural reforms aimed at increasing labour market flexibility became a recurrent mantra. The stated goal was to heal the "Eurosclerosis" disease, the rationale being that more flexible labour market institutions could foster economic dynamism by reallocating resources to more productive firms and enabling firm restructuring. The emphasis on labour market reforms is still present today, even if in a very different macroeconomic environment. As it often happens, labour market reforms took the path of least resistance. While workers with open-ended contracts, at the core of trade unions' constituencies and with plenty of political representation, went relatively unscathed, at least in a first period, it is through liberalisation of fixed-term contracts 
that more flexibility was introduced into the system (Berton, Richiardi and Sacchi 2012). It was the season of reforms at the margin, which increased the proportion of temporary jobs in most countries, currently reaching almost $15 \%$ of the workforce in the European Union as a whole. Given that temporary workers are generally weaker than permanent workers, with a negative wage premium - after controlling for individual characteristics - of up to 20\% (Berton, Richiardi and Sacchi 2012), this change was regressive, contributing to the polarization of income. However, the introduction/expansion of temporary contracts might have led to lower unemployment, with a counterbalancing effect on inequality (Booth, Francesconi and Frank 2002). This is not enough, however, to change the direction of the effect: for instance, using LIS microdata for 22 OECD countries from 1985 to 2014, Weisstanner (2017) shows that income shares of the middle and lower-middle quintiles decline under deregulated temporary employment. More in general, reforms aimed at increasing labour market flexibility have also generally contributed to what Hacker (2008) has called "the great risk shift", with market risks being shifted from firms to workers - in terms of functional distribution, from the richest owners of capital to weakest suppliers of labour.

\subsection{Product Market Power}

Product market power refers to the capacity of firms to alter the prices of their products whilst remaining profitable; it implies a negatively-sloped demand for the firm's product. Product differentiation - e.g. through branding - is one common way firms build up market power. Other common sources are regulatory or technological barriers to entry and imperfect information of consumers about alternative products. Since these sources of market power can be heterogeneous across firms, there is an interest in measuring market power for individual firms.

Just as in the case of labour market power, an elasticity at the firm level is the ideal measure of product market power. Yet, because of the one-to-one relationship between the elasticity of demand and the mark-up of the firm (defined as price over marginal cost), the latter is usually the object of interest of empirical studies, with higher mark-ups implying greater market power. ${ }^{13}$

Unlike labour market power, the consequences of product market power for inequality are less evident. On the one hand, less competition means a greater concentration of profit among large, "superstar" firms, which are known to have a lower labour share (e.g. Autor et al. 2017)). In consequence, the aggregate labour share falls. The outcome of this functional distribution of income translates into the personal distribution of income through the uneven ownership of income sources across households, particularly in capital and firm ownership. On the other hand, changes in product market power can induce general equilibrium effects through changes in labour market power, employment and wages. Starting with the seminal paper by Blanchard and Giavazzi (2003), this interdependence between product and labour market power has received a great deal of theoretical and empirical attention. ${ }^{14}$ The latter has been particularly motivated by recent reforms toward product and labour market deregulation in advanced economies.

Further channels through which product market power might affect inequality are discussed latter. It must be noticed here however that product market power is not totally exogenous. As suggested in the "superstar" and trade literature, mark-ups are partly driven by trade liberalisation and

\footnotetext{
$\mathrm{p} \stackrel{13}{=}$ n particular, if mark-up is denoted as $\mathrm{p}$, and the elasticity of demand is denoted as $\epsilon$, their relationship given by $\mathrm{p}=\frac{1}{1+\square}$, where $\epsilon<-1$.

${ }^{14}$ There seem to be no comprehensive review of this literature available, except for a relatively brief summary by Cacciatore and Fiori (2015) in the context of a book review.
} 
technological change..$^{5}$ Any proper analysis of the effect of product market power on inequality requires studies that control for these factors.

It is not a surprise that firms do have some degree of market power, and that such power is heterogeneous across firms, industries and geographies (for an early review, see Bresnahan 1989; for a more recent review in the context of international trade, see Tybout 2008). But has such market power at the firm level changed in recent decades? In the US, mark-ups seem to have increased in the last decades. In a widely cited paper, De Loecker and Eeckhout (2017) use firm level data of US publicly traded companies and from the US census of manufacturing, finding a marked increase in mark-ups since the early 1980's. For instance, they calculate a mark-up of $67 \%$ over marginal cost in 2014 (the highest since the data starts, in 1950), versus 18\% in 1980. These results are however challenged by Traina (2018), who uses the same data, but implement an alternative definition of mark-ups, namely one which considers "indirect costs of production such as marketing and management" (p.2), which they show to have risen considerably over the last decades. Under their calculations, mark-ups have increased only marginally since 1980. In fact, when accounting for the over-representation of large firms in the data (being publicly listed firms), mark-ups have actually fallen since 1980.

In the case of Europe, results are inconclusive. On the one hand, Deutsche Bundesbank (2017) use firm level data for seven European countries, covering the 27 industries over the 1996-2014 period, finding stable mark-ups pre-recession, with a fall afterwards. ${ }^{16}$ This result seem consistent with Weche and Wambach (2018), who use a sample of more than 3.6 million firms, covering 18 European countries for the 2007-2015 period, and finding a sharp fall in mark-ups during the Great Recession, with some partial recovery afterwards. This pro-cyclical behaviour of mark-ups has also been documented for the US (e.g. Anderson, Rebelo and Wong 2018). On the other hand, replicating their previous study for the US referred above to other countries, De Loecker and Eeckhout (2018) find a sustained increase in mark-ups among 16 European countries, between 1980 and 2016, with a significant rise after the Great Recession. The magnitude of the increase is actually comparable to that in the US. Although there are clear data and methodological differences among the studies (with De Loecker and Eeckhout 2018 merely importing some essential parameters from their previous US estimation into Europe), in our view none of them is necessarily superior.

For countries beyond the US and Europe, mark-up estimates are scarce. The best comparable evidence available so far is again from De Loecker and Eeckhout (2018), who compute mark-ups for 134 countries, using data on publicly traded companies, from 1980 to 2016. Minding the highly selected sample (in terms of country and firms), overall they find an increase in "global mark-ups", albeit with substantial heterogeneity in terms of magnitude and timing. Among OECD countries, only Chile and Turkey saw a fall in mark-ups over the period. ${ }^{7}$ Diez, Leigh and Tambunlertchai

'5A significant number of firm-level studies suggests a pro-competitive effect (e.g. a reduction in mark-ups) of trade liberalisation and import competition, both for developed and developing countries (e.g. Alfaro and Chen 2018; Bottasso and Sembenelli 2001; Chen, Imbs and Scott 2009; Edmond, Midrigan and Xu 2015; Feenstra and Weinstein 2017; Konings and Vandenbussche 2005; Levinsohn 1993). However, De Loecker et al. (2016) have pointed out potential biases in previous analyses, arising from ignoring reductions in input prices, which together with reductions in output prices are also observed in episodes of trade liberalisation. These authors, together with Fan et al. (2018), provide evidence that accounting for input tariff reduction shows exporters increased mark-ups after an episode of trade liberalisation, partly because reduced costs are not passed through completely to consumers. Other theoretical papers have highlighted the rather ambiguous effect trade liberalisation can have on mark-ups (e.g. Arkolakis et al. 2018; Behrens et al. 2014). For a recent review of firm-level studies on trade and mark-ups see De Loecker and Biesebroeck (2018).

${ }^{16}$ Countries included are Austria, Belgium, Denmark, Finland, France, Germany and Italy.

${ }^{7}$ Mark-ups can also be computed at a more aggregate level using national accounts data. The validity of this 
(2018) use the same dataset and period than De Loecker and Eeckhout (2018), albeit focusing on 74 only, arriving at similar conclusions.

Whilst mark-ups are the ideal measure of product market power, less data-rich proxies have been suggested in the literature. The long-standing alternative indicator of such market power is a measure of market concentration, e.g. the Herfindahl-Hirschman index (HHI henceforth). ${ }^{18}$ Grullon, Larkin and Michaely (2017) computes this index for most of US publicly-listed firms available, distinguishing a period of decreased market concentration (1983-1996) followed by a period of increasing market concentration (1996-2011), peaking at lower levels than its maximum in 1983. This pattern - common across most US industries - is not so much consistent with the relatively constant upward trend in mark-ups documented by De Loecker and Eeckhout (2017) since 1980, perhaps an indication that market concentration is not per se an indicator of market power (e.g. technological change and globalisation might enable greater economies of scale, leading to the optimal size of the largest firms - usually exporters - to grow; e.g. see Klaus Walde and Pia Weiss 2007). Using a different dataset of US firms, Rossi-Hansberg, Sarte and Trachter (2018) also find increasing concentration in terms of HHI index at the national level for the 1990-2014 period, but document a fall in concentration at the local market during the same period (measured at the county or smaller geographical level, like ZIP codes). The authors suggest this could be due to the biggest firms opening plants in new markets, which lowers concentration on the latter (as competition with local incumbents increase) whilst still increasing their overall share with respect to the wider economy. Yet again, the fact that bigger companies can take advantages of economies of scale or other factors to increase their mark-up vis-a-vis competitors means local market concentration might not be a good proxy for product market power.

Among European industries and countries, increased concentration is rather unsupported by the data. Deutsche Bundesbank (2017) finds either decreasing or stable HHI across industries in seven European countries, between 2000 and 2012. Exceptions are the manufacturing sector in countries like Germany and France, which appear to become more concentrated over the period. Using firmlevel data for 14 European countries, covering the 2000-2015 period (when possible), Gutierrez (2017) also find no evidence of increasing market concentration.

Turning now to empirical assessments of the effect of mark-ups on inequality itself, unfortunately there seems to be no micro-data study robustly estimating such relationship whilst controlling for other factors, particularly trade. Perhaps the closest study to such goal is provided by Shepotylo and Vakhitov (2012). They use a sample of manufacturing firms from Ukraine, between 2001 and 2007, to evaluate the effect of productivity, mark-ups and other variables on wages. They find a positive but low effect of mark-ups on wages. However, it is impossible to tell the extent to which

method however depends on strong assumptions, including the existence of a well-behaved aggregate production function. A recent example of such exercise is Han (2015), who computes mark-ups for 18 developed countries (plus China, India, Indonesia and South Africa), between 1950 and 2011. The overall picture arising from firm-level studies is confirmed with this data. Developed countries no mentioned so far which also observe an increase in mark-ups since 1980 are Australia and New Zealand, whereas countries where mark-ups have fallen over the period are Canada, Japan, and South Korea. Hall (2018) provides a novel method to estimate mark-ups also using aggregate data (which still relies in the assumption of a well-behaved aggregate production function). They find increased mark-ups in the US for the period under study, 1988-2015.

${ }^{18}$ Not all agree that market concentration is related to product market power. For instance, the efficiency hypothesis, associated with the Chicago School (e.g. Demsetz 1973), suggests that higher concentration arises because more efficient firms are more profitable, thereby gaining market share and size, rather than because of uncompetitive behaviour. This situation can hold even in contestable markets. For further analysis, see Cabral (2017). Empirically, Hall (2018) finds no relationship between firms' market share in terms of employment and mark-ups among US largest firms. 
factors like trade integration are driving changes in mark-ups, and their ultimate effect on inequality. The second best source of evidence comes from aggregate data. Han (2015) is, to the best of our knowledge, the only paper studying the direct effect of mark-ups on a measure of inequality, whilst controlling for other covariates, including openness to trade. Han evaluates the effect of mark-ups on several inequality indexes using a panel of 22 countries (of which 18 are developed countries), covering the 1961-2004 period. The results indicate a considerable positive effect of mark-ups on the top $5 \%, 1 \%$ and $0.1 \%$ income shares, a negative one on the share of income of those between $10 \%$ and $5 \%$, and no effect on the bottom 90\%. Meanwhile, Barkai (2016) uses US industry level data to demonstrate that the increase in mark-ups explain almost all the fall in the labour share observed between 1997 and 2012. Mark-ups are however not observed in the data, and are proxied by an index of concentration, namely the share of sales by the largest firms. As mentioned earlier, the extent to which concentration is linearly related to mark-ups remains unclear.

Other studies focus on the effect of mark-ups on the return to capital and interest rates, from where we can infer further consequences to inequality. Rovo (2017) studies 15 advanced economies, between 1980 and 2008, also using aggregate data. ${ }^{19}$ She finds that higher mark-ups lower interest rates. Since the latter is known to increase asset prices, such fall in competition benefits richer households disproportionately, thereby increasing inequality. Another study is Brun and Gonzalez (2017). They show theoretically that an increase in mark-ups increases the return to equity and the Tobin's Q - partly because higher market power increases the prospects of profits and thus raises the value of firms. Here again, given unequal ownership of capital across households, inequality is increased. In their model, the labour share falls. A calibrated version of the model for the US between 1970 and 2010 shows a considerable role of higher mark-ups in explaining the fall in the labour share over the period.

Product market power, together with corporate governance and norms, also plays a key role in how rewards to top managers are determined. The past few decades have witnessed profound changes in remuneration systems for top managers, involving spectacular increases in their overall remuneration and a compositional shift in compensation towards incentive pay and stock options (Cuñat and Guadalupe 2009a). For instance, the remuneration of top executives in the US has risen from about 30 times the compensation of an average worker to about 300 times, and incentivebased pay accounts for more than 70\% of CEO compensation in large US companies (MSGI 2016). This has been shown to play a substantial role in the increasing concentration of income at the very top (see Atkinson, Piketty and Saez 2011 for an overview; Denk 2015, for European countries; Piketty, Saez and Zucman 2018 for the US; and Bell and Van Reenen 2014, for the UK).

Overall, it is evident there is a fairly rich theoretical literature linking product market power and inequality lacking robust empirical assessment, particularly at the micro-level.

\subsection{Demography, Household Structure and Participation}

Inequality is strongly affected by the changing composition of the population, in terms of age and family structure, and changing patterns of household labour force participation. (These in turn may be significantly affected by the migration flows noted earlier).

\footnotetext{
${ }^{19}$ As already stated in footnote 15 , the measurement of mark-ups using aggregate data is based on strong assumptions. Han (2015) assumptions are less restrictive than those in Rovo (2017). In effect, the latter yields trends for mark-ups which are in many countries (including the US) at odds with those from firm-level data, casting doubts on the validity of the assumptions, and thus on the results. In our view the channel is however worth mentioning.
} 
Rich countries have seen an early onset of population ageing, at varying rates, due to increased longevity and low fertility rates. Over recent decades, life expectancy has continued its growth of about one quarter per year while fertility declined dramatically, falling in OECD countries from 2.7 children per woman of childbearing age in 1970 to 1.7 in 2014, well below the replacement level of 2.1. These trends together were reinforced by the post-WWII baby boom, a process of demographic transition which will continue until that generation dies out.

At the global level population ageing is a much more recent phenomenon. Between 1980 and 2015 the global labour supply still increased by over 50 million workers a year, on average, as widespread decreases in mortality rates were not matched by decreases in the fertility rates. This resulted in a steep decline in the world dependency ratio, which undoubtedly favoured the owners of the factors of production which are complementary to (mainly unskilled) labour, namely skilled labour and capital. This trend however is now reversing: by the mid of the century, only Africa will be still experiencing an expansion in its labour force.

The effects of population ageing on inequality are manifested through three main channels (Goldstein and Lee 2014). First, in a standard Solow growth model, the long run growth rate of aggregate income equals the rate of productivity growth plus the rate of population growth and the depreciation rate; capital intensity is equal to the saving rate divided by the growth rate. With an approximately constant saving rate, slower population growth implies slower growth of the economy and higher capital intensity. Because wealth is far more unequally distributed than labour income, increasing capital intensity generally results in greater income inequality, as highlighted by Piketty (2014). ${ }^{20}$ Second, income differences within age groups tend to grow over the lifetime, while the fact that younger people have earnings that are typically below the average becomes less important as the share of younger people diminishes. Third, people tend to save in their prime age, and use their savings at later ages. Hence, longer periods of life-cycle savings imply greater differences in wealth accumulation. Goldstein and Lee (2014) look at the expected effects of these three mechanisms on the income share of the top decile, in the decades until the demographic transition is over. They find a significant impact for the US (about 7 percentage points), and an even higher impact in Europe, where demography alone could lead to more than doubling the increase in inequality seen in recent decades.

Another secular trend with major implications for inequality at household level is the increased labour force participation and employment rates of women. Female attachment to the labour force has increased by more than 10 percentage points on average in OECD countries, and more than 20 percentage points in Europe, since the early 1980s, although the United States have displayed a negative trend in the past 15 years - mainly explained by demographic factors (Abraham and Kearney 2018). The increased workforce participation of women has for the most part served to cushion household incomes from the effects of increasing dispersion among individuals (Gonzalez and Surovtseva 2016; Hoynes and Schanzenbach 2012) and reduce overall household income inequality. The OECD estimates that if the proportion of households with a working woman had remained at around the same levels as in the mid-1980s, income inequality would have increased by almost 1 Gini point more than it did (OECD 2015). An increase in assortative mating, choosing a partner

\footnotetext{
${ }^{20}$ However, diminished labour supply means higher real wages, in the short run. In the longer run, this could induce a substitution between labour and capital. For instance, Abeliansky and Prettner (2017) show that slower population growth leads to faster automation. Using panel data for 60 countries over the period 1993-2013, they find that a $1 \%$ decrease in population growth is associated to a $2 \%$ increase in the growth rate of robot density.
} 
coming from the same socio-economic group, is generally considered to be only a minor contributor to inequality (Greenwood et al. 2014, 2016), but raises concerns for the evolution of inequality in the future (Milanovic 2016).

\subsection{Redistribution}

Finally, and crucially, we come to redistribution of market income by the state via taxation and social expenditure. While offsetting some of the increase in inequality in market incomes among households, the effectiveness of direct taxes and transfers has been shown to have often weakened in recent decades, contributing significantly to rising inequality in disposable incomes. Immervoll and Richardson (2011), for example, on which the influential OECD (2011) report draws, looked at longer-term trends in redistribution and overall inequality in the decades preceding the Great Recession at country level with data derived from survey micro-data. They found that for workingage households, tax-benefit systems became more redistributive from the 1980s to the 2000s, but that market income inequality still grew by twice as much as redistribution. The redistributive strength of tax-benefit systems weakened from the mid-1990s to the mid-2000s, and that was often the main reason why inequality rose over that decade. This reflected on the one hand the ways in which social protection systems evolved, often privileging pensioners at the expense of working-age recipients while struggling to adapt to increasing levels of low pay and in-work poverty, and with social safety-nets sometimes weakening as coverage and generosity of working-age benefits were cut back. Top income tax rates were generally reduced from the late 1970s onwards, and in some cases taxes on income from capital were reduced even more, both because these measures were seen as encouraging economic activity and because of the competitive pressures this wave of reductions created across countries (Joumard, Pisu and Bloch 2012).

The redistributive impact of transfers and direct taxes in reducing inequality in disposable versus market incomes generally increased during the initial stages of the economic crisis. This was reflected a rise in public transfers and fall in incomes taxes, in a more pronounced version of the standard cyclical pattern in 'automatic stabilisers', reinforced in some instances by fiscal stimulus packages which amplified this redistributive effect (Causa and Hermansen 2017; see also Dolls, Fuest and Peichl 2011; Jenkins et al. 2013). In the US, for example, redistribution through taxes and transfer programs reached historically high levels in 2010 (Perri and Steinberg 2012). However, survey data shows that overall redistributive impact weakened or stagnated in most OECD countries from about 2010. This reflects the impact of fiscal consolidation measures and withdrawal of fiscal stimulus in some countries, and the reduction in 'automatic stabilisers' as recovery got under way. Country experiences varied widely, with fiscal consolidation and cut-backs in social transfers having a much more marked impact in some than in others (De Agostini et al. 2014; OECD 2015; Bargain et al. 2017). However, Nolan (2018) shows that the decline in redistributive impact seen from the mid-1990s to the mid-2000s was not reversed in most cases by 2014, indeed, it often declined further. However, in the countries worst hit by the Great Recession, notably Greece, Ireland, Italy, Portugal and Spain, redistributive impact was markedly higher in 2014 than before the crisis.

Beyond the immediate impact of tax and transfer policy shifts on disposable incomes, they may have had substantial effects on the distribution of income from the market. In particular, the widespread marked decline in top tax rates has been seen as helping to fuel the rise of the top income shares. The striking relationship between the two over time in the case of the United States has been highlighted by Piketty and Saez (2007), and a strong negative relationship between the 
marginal tax rate and the top income share in pre-tax income is also to be seen at a cross-country level (Alvaredo et al. 2013). Testing a model of CEO pay using micro data for the US and other 12 developed countries, Piketty, Saez and Stantcheva (2014) find empirical support for this role of marginal tax rates on income inequality; a cut in rates may increase top income shares as a result of reduced tax avoidance/evasion and increased incentives to work, but Piketty et al also emphasize the increase in incentives to extract pay rises and economic rents. The list of papers empirically studying the effect of government spending on inequality is very long. Some insights come from a metaregression analysis by Anderson et al. (2017), covering 84 of these. Unexpectedly, they find that the direction and magnitude of the effect varies considerably with (among other things), (i) the definition of inequality (in particular suggesting that redistribution is particularly beneficial for the middle class), (ii) the inclusion of developed countries in the sample (unsurprisingly given that redistribution is much more effective in reducing inequality in these countries), and (iii) the estimation method (which speaks of potential reverse causality needed to be addressed). ${ }^{21}$

The role of corporate as well as individual taxes must also be taken into account, especially in the context of globalisation. Tax competition across countries has been one of the factors pushing down corporate taxes as well as marginal tax rates on individuals, putting pressure on indirect taxes and social expenditure. Fuest, Peichl and Siegloch (2018) using micro-data for German municipalities show that corporate taxes also impact on wages, with much of the burden born by medium and higher-skilled workers, principally because they are taken into account in wage bargaining. An analysis by Nallareddy, Rouen and Suárez Serrato (2018) across US states highlights a separate channel of influence, whereby corporate tax cuts lead to increasing income inequality, as some top earners shift their income to reduce taxes. This brings out the importance of going beyond conventional measures of direct redistribution among households in assessing the role of taxation. A similar point may be made about the importance of incorporating social spending going beyond cash transfers, to take the contribution to living standards of state-provided or subsidised services in health, education etc., but this would take us beyond the focus on inequality in cash incomes adopted here.

\section{An encompassing framework and assessing the role of dif- ferent inequality drivers}

\subsection{The complexity of the casual structure}

In Section 3 we have examined recent studies focusing on specific drivers of inequality. However, the overall causal structure between economic and political developments and inequality is complex, with many feedbacks and interconnections. Figure 5 is an attempt at providing a description of the complex interlinks between drivers. While more complex than similar schemes proposed in for instance OECD (2011) or Forster and Toth (2015), this representation is still a simplification as it includes only the most important factors and feedback channels identified by the literature. The figure represents how the demand and supply of both capital and labour are determined. Demand for capital and labour stems from production needs, which in terms depend on technology and the organization of markets, within and across countries, and on the overall level of demand for output, as expressed by both domestic and foreign customers. The supply of labour depends on

\footnotetext{
${ }^{21}$ The authors also find evidence of publication bias towards results showing a positive effect of spending on inequality for studies using total spending, and a bias towards negative results when using social welfare spending, perhaps reflecting prior (ideological) expectations.
} 
demographic factors and on market incentives, as shaped by the legislation. The supply of capital depends on aggregate savings and the functioning of capital markets. The interaction between demand and supply determines labour and capital income, which feed into disposable income via the tax-benefit system. The distribution of disposable income then determines the level of inequality. The strength of the causal links along the pathways and feedbacks crucially depend on the broader social and political framework.

In this schematic representation, diamond shapes indicate drivers, boxes indicate intervening (or mediator) variables, solid lines with arrows show the main pathways, and dotted lines with arrows indicate key feedbacks. All variables which can be defined at an individual level refer to their entire distribution.

Globalisation and technological change - "the twin forces $[\ldots]$ that are radically reshaping the labour markets of rich and developing countries" (Atkinson 2015, p.3) - are grouped together in the top oval, labelled "production" to signal that these forces mainly affect the process of production. Globalisation however also affects aggregate demand, through net exports and diverted investments. Finance both influences and is influenced by technological change and globalisation: availability of credit fosters innovation and entrepreneurship, and makes it easier for companies to operate on a global scale. At the same time, innovation in financial instruments and the financial structure (mainly thanks to ICT) improves the scope for financial intermediation. Finance also affects the level of aggregate demand through the availability of credit.

Globalisation, technological change and finance also have an impact on the market structure, mainly through changes in market concentration. So, their effect on the demand for capital and for different types of labour (skilled and unskilled, executive and non-managerial) is both direct through changes in the production function, hence the productivity of each factor, and changes in the demand for output - and indirect - through changes in market structure involving a redistribution of market power both upstream, in the factor market, and downstream, in the product market (e.g. through the increase in global labour competition, lowering the bargaining power of workers). Changes in the market structure like the emergence of global markets, strong network-effect and winner-takes-all markets might lead to greater market concentration, a rise in profits for top firms and a subsequent fall in the labour share. This spurs short-term behaviour in finance (e.g. stock-buybacks), lowering innovation and long-term investment, and negatively affecting the demand for capital.

The outcomes of these economic processes - labour income and capital income, depend also on the supply side. Labour supply is determined, among other things less relevant here (for instance, social norms), by socio-demographic characteristics, in particular demography (the age structure of the population), household composition (characteristics of the partners, number and age of children), and education. The degree of endogamy, or assortative mating, is part of the 'household composition' channel. Demography, household composition and education are grouped together in the oval on the left, labelled "population". As said below, labour supply decisions also depend on the tax and benefit system. Meanwhile, capital supply depends, in addition to savings, on the structure of the financial sector, together with monetary policy and regulation.

Market outcomes (labour and capital income) are then transformed into disposable income through the functioning of the tax and benefit system. Disposable income determines individual consumption 
Figure 5: The Drivers of Inequality

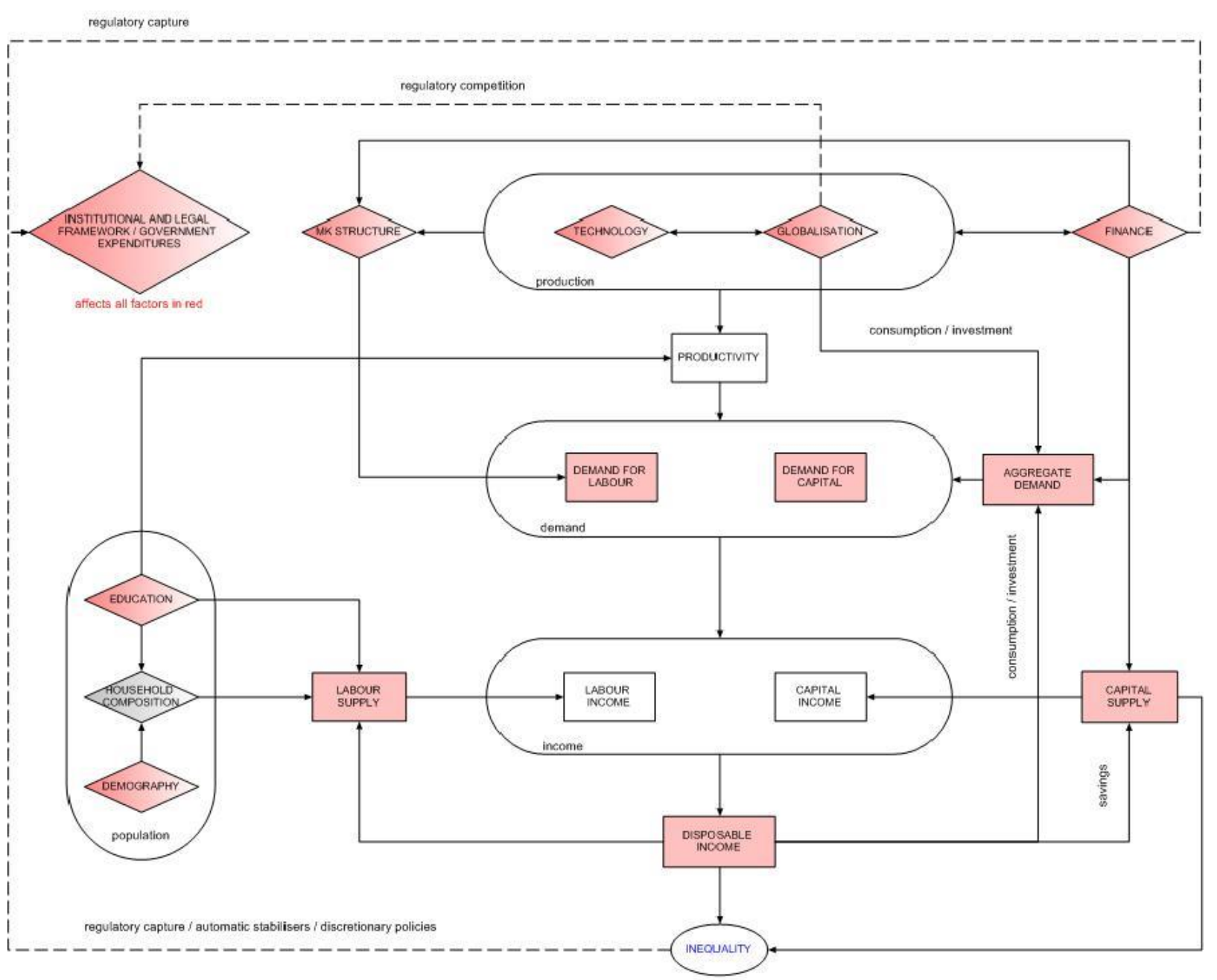

Source: Authors' elaboration 
and savings (hence, the accumulation of wealth and capital supply, from which, through the intermediation of the financial system and the operation of capital taxation, capital income is derived), and aggregate investment. Disposable income hence determines, together with foreign demand and government expenditures, the aggregate demand for output, hence looping into the demand for the production factors, capital and labour. The distribution of disposable income and wealth then determines economic inequality.

The institutional and legal framework, including automatic stabilisers and discretionary policies, affect most of the drivers and intermediate variables (all those coloured in red in Figure 5). To start with, the tax and benefit system affects the decisions of both firms and workers/households. Moreover, the institutional and legal system affects market structure (e.g. through the operation of antitrust laws), innovation and technological change (by defining constraints through standards, and incentives through the patent system), globalisation (through tariffs and other protectionist measures), the functioning of the financial system (through regulation), the conduct of monetary policy (which affects the demand of labour and capital), demography (by means of family policies and immigration laws), and education (by mandating a minimum level of compulsory education, subsidising supply and incentivising demand). The institutional and legal system also affects the demand for the factors of production - labour and, indirectly, capital - through labour laws and the system of industrial relations. In particular, minimum wage and employment protection legislation, by increasing the bargaining power of workers, have a profound impact on the wage structure and levels, with an inequality-reducing effect. Finally, government expenditures have a direct impact on aggregate demand, and might have an indirect impact through the investment decisions by firms.

The institutional and legal system can also be influenced by globalisation - through the mechanism of regulatory competition, the threat that businesses will either move to or succumb to competition from countries with a more favourable system of incentives - and by the increased concentration of power in the hands of a restricted economic and financial elite, which might use it to implement regulatory changes that are even more favourable to them (regulatory capture).

Note that government expenditures are not fully exogenous, as they are aimed at correcting in one way or another specific social and economic outcomes - not necessarily limited to inequality, thus adding further feedback loops (not shown in the diagram).

In conclusion, the dynamics of inequality can be represented as the result of many forces pulling in different directions, and their interactions and effects may well differ across countries rather than producing a common outcome.

\subsection{Assessing the role of different drivers}

A complex causal structure as the one depicted in Figure 5 is hard to be taken to the data. Indeed, the amount of causal loops in the figure suggests that distributing the observed effect to each of the individual determinants is probably misleading. Statements of the type "the increase in inequality is due for $\mathrm{x} \%$ to driver $\mathrm{A}$, for $\mathrm{y} \%$ to driver $\mathrm{B}$, and for $\mathrm{z} \%$ to driver $\mathrm{C}$ " imply no interaction between $\mathrm{A}$, $\mathrm{B}$ and $\mathrm{C}$. Accounting for more interactions - possibly happening at different aggregation levels and time scales - is more accurate, but leads to indecipherable statements and doubtful quantification, given the available data. As the American journalist Henry Louis Mencken once put it, "for every complex problem there is an answer that is clear, simple, ... and wrong". While the research 
question remains central in economics, arriving at an overall assessment of the relative importance of these various factors in driving inequality upwards across the rich countries is therefore an inherently hazardous exercise. While the research literature is rich in partial analysis focusing on specific determinants or individual countries, it has far fewer studies with truly multivariate and multicountry specifications, and these struggle to incorporate the range of potential factors and how they may interacts with each other. Without attempting a comprehensive listing, here we highlight some influential multicountry studies that include a broad range of economic and institutional factors and seek to assess their relative importance, and use these to illustrate the challenges faced by such exercises.

The IMF study by Jaumotte, Lall and Papageorgiou (2013) using country-level data found that for developed countries, the adverse impact of globalization on the Gini coefficient for household income inequality was slightly larger than that of technological progress, with these being the dominant factors. Their analysis was based on a loglinear relationship between the Gini coefficient and various measures of trade and financial globalization, technological progress, education, sectoral composition and domestic financial development. No interaction effects and no lags were considered.

The more recent IMF study by Dabla-Norris et al. (2015) also based on country-level data received a great deal of attention. This is also based on a simple linear relationship, this time between overall income inequality (both market and disposable, for households) and trade globalisation, measured as the sum of exports and imports as a share of a country's GDP; financial globalisation, measured as the sum of foreign assets and liabilities relative to GDP; technology, as proxied by the share of information and communication technology capital in the total capital stock; domestic financial development, measured as the ratio of private credit to GDP; education, measured by the average years of schooling in the population aged 15 and older; inequality of opportunities, as proxied by the Gini coefficient for educational attainments and the female mortality rate; the employment protection legislation index for labour market flexibility; policies, measured as total government spending as a share of GDP; and the quality and availability of health systems, measured by the female mortality rate. The analysis is based on a sample of almost 100 developed and developing countries over the period 1980-2012, looking at both market and disposable income inequality. For advanced countries, the results suggest that the increasing level of educational attainments (which they consider a proxy for the skill premium), deregulation in the labour market, and globalisation are the main drivers of increasing market income inequality. One can ask a number of questions related to the choice of the control variables and their interpretation: for instance, why average educational levels should be considered as evidence of the skill premium, why the skill premium, which is an outcome, should be considered as a determinant of inequality, and how one can interpret the effects of technology, which may operate through the skill premium, if that premium is itself included.

Another country-level study on a large number of countries, by Peters and Volwahsen (2016), considers the following determinants: globalisation, measured (rather oddly) as the share of Chinese imports on total imports; technological change, measured by investments in ICT; financial openness; migration; labour market regulation, for which they use an index describing how binding the minimum wage is and (again rather oddly) the unemployment rate; bouse prices; and business cycle effects. They find that in the period 1995-2013 the main drivers of (market and disposable household) overall income inequality are globalisation, technological change and migration.

The influential report from the OECD (2011) focused on inequality in household earnings among 
working-age households. With county-level data it looked at the effects of three main drivers: globalisation, technological progress, and institutions, for 22 OECD countries between the early 1980s and the late 2000s. Globalisation is measured with a set of indicators looking at both trade and financial movements. Technology is measured by the share of R\&D private expenditure on GDP, or alternatively patents, trade performance of R\&D-intensive industries, and ICT intensity. Institutional variables include trade union density and coverage, the degree of centralisation and co-ordination in wage bargaining, the strictness of employment protection legislation, the level of product market regulation, the size of the tax wedge, and unemployment benefit replacement rates, and minimum wage. Controls include the sectoral composition of the economy, the educational structure of the population, the share of female employment, and the output gap as a measure of business cycle. The analysis exploits within-country temporal variation of each determinant: the effect of each determinant is assumed to be the same in all countries, but each country has specificities which are assumed to be constant over time and contribute to explaining why countries with similar characteristics might have different levels of inequality. The conclusions stress the role of labour market policies and institutions and technological change in explaining the increase in household earnings inequality, with trade integration and international financial flows having little distributional impact. The rise in educational attainment is seen to have contributed substantially to offsetting the rise in inequality due to technological, institutional and policy changes, and rising female labour force participation also exerted a sizeable equalising effect. The analysis confirms Tinbergen's intuition of a "race between education and technology", although mediated by institutions and policies: education won the race, but institutions and policies decide who gets the prize.

The reader could try leaving out some of the causal links in Figure 5 to replicate the specification of these multivariate analysis. While some more naive ones would leave only a few links left, others get closer to what is possible to do, given data limitation. The question is then, is the best that can be done good enough. In particular, the OECD study features extensively in Forster and Toth's (2015) review of a wide range of comparative studies of the drivers of inequality in OECD and EU countries, from sociology and political science as well as an economics perspective. While several of the papers mentioned here have appeared since their review was completed, their discussion serves to bring out why such multivariate analyses find it so difficult to arrive at consensus on the relative importance of different factors in driving trends in inequality, indeed even to identify robustly that specific have a significant impact. The inconclusiveness of results from such analyses is analogous to the similarly-structured literature seeking to quantify the drivers of economic growth; both face the combination of too many competing explanations, too few countries, and too short time-series often with non-comparable definitions of key variables.

We would also argue that the importance of institutions and policies is likely to be under-estimated by such aggregate-level comparative modes of analysis of inequality trends, given how difficult it is to adequately capture the nuances of institutional and policy change in the types of high-level variables they include. This serves to highlight the value of in-depth investigation of individual country experiences, particularly when framed in a comparative perspective with a common analytic lens (such as the 30 European case-studies presented in Nolan et al. 2014, and the ten OECD countries examined in depth in Nolan 2018). Such studies can go much further in tracing the links from changes in institutional settings and policy parameters to household incomes, and often show a substantial correspondence between such changes and episodes of rising inequality at the individual country level. 


\section{Conclusions and Implications}

The recent upsurge in research on income inequality, the focus of this survey, has largely been motivated by the striking increases in inequality seen in certain rich countries, most notably the US, over decades. Our review of how inequality actually developed across the OECD, drawing on a variety of sources, brought out that there have been marked differences in trends across countries and time-periods. Global economic forces such as globalisation and technological change have clearly interacted with national ones, with institutional structures and policies filtering the impact of what are widely seen as common exogenous drivers (though that description is itself highly questionable). The importance of the US in the global economy, the extent of the increase in inequality there, and American dominance of economics as a discipline mean that the findings of US-focused research can often be taken to have general applicability, but our review has served to highlight that this can be seriously misleading.

While a comparative perspective can serve as an important corrective, we have also noted how difficult it is to arrive at a consensus on the relative importance of different drivers of inequality via aggregate cross-country regression analysis, and why that will continue to be such a challenge. There is much more agreement on the range of factors which are likely to have impacted on inequality, via the mechanisms we have discussed in depth in this review for each driver, than there is on their individual contributions and on how that would serve to explain why inequality has risen much more in some countries than in others. This reflects both the limitations of this sort of analysis given the data available, and the complexity of the likely interactions between the various drivers, not least between globalisation and technology and between these and institutional structures. This serves to highlight the importance of complementing aggregate cross-country econometric analyses with in-depth investigation of individual country experiences, especially when examined through a common analytic lens, where the often episodic nature of inequality increases can be more adequately contextualised.

Another implication is that studies based on micro-data can also be particularly revealing about the specific channels by which the different components of household income are influenced by various drivers. In that context, monopsony power is a particularly important area for further investigation, especially incorporating the time dimension. More evidence on the evolution of market power in both product and labour markets, and the role it plays in recent inequality trends, is a particular priority. The relationship between firm-level measures and more traditional aggregate-level measures are largely unexplored, and the existing evidence is heavily concentrated on the US to data. Product and labour market power are also generally examined separately in empirical studies, in contrast to some theoretical contributions (e.g. Azar and Vives 2018; Blanchard and Giavazzi 2003). A related area which has received little attention is market power with respect to access to capital: firms can increase their economic rents not only by exercising market power to hold down wages, but also by using it to obtain cheaper financing than competitors. The role of monetary policy in influencing inequality directly and indirectly is also only now stating to receive the attention it deserves, and understanding this better will be particularly important as central banks seek to unwind the unprecedented measures employed in the wake of the global financial crisis.

Much has been learned from recent research about the complex web of inter-related drivers of income inequality. However, this review has brought out the extent to which this still leaves a 
fragmented, incomplete, and sometimes contradictory research landscape. While consensus in such an ideologically-charged area may be too much to hope for, more, and more focused, research along the lines discussed here can realistically aspire to substantially narrowing the scope for legitimate disagreement respecting the empirical evidence. 


\section{References}

Abeliansky, Ana and Klaus Prettner (2017). Automation and demographic change. Center for European, Governance and Economic Development Research Discussion Papers 310. University of Goettingen, Department of Economics.

Abowd, John M., Francis Kramarz and David N. Margolis (1999). 'High Wage Workers and High Wage Firms'. In: Econometrica 67.2, pp. 251-333.

Abraham, Katharine and Melissa S. Kearney (2018). Explaining the Decline in the U.S. Employmentto-Population Ratio: A Review of the Evidence. NBER Working Paper 24333. National Bureau of Economic Research.

Acemoglu, Daron (2002). 'Technical Change, Inequality, and the Labor Market'. In: Journal of Economic Literature 40.1, pp. 7-72.

Acemoglu, Daron and David Autor (2011). 'Skills, Tasks and Technologies: Implications for Employment and Earnings'. In: Handbook of Labor Economics. Ed. by David Card and Orley Ashenfelter. Vol. 4.B. Elsevier, pp. 1043-1171.

Acemoglu, Daron and Pascual Restrepo (Mar. 2017). Robots and Jobs: Evidence from US Labor Markets. NBER Working Paper 23285. National Bureau of Economic Research.

Alfaro, Laura and Maggie X. Chen (May 2018). 'Selection and Market Reallocation: Productivity Gains from Multinational Production'. In: American Economic Journal: Economic Policy 10.2, pp. 1-38.

Almeida, Vanda (Dec. 2016). Income Inequality and Redistribution in the Aftermat of the 2007-2008 Crisis: The US Case. Available at SSRN: http://dx.doi.org/10.2139/ssrn.2670586.

Alstadsæter, Annette, Niels Johannesen and Gabriel Zucman (Sept. 2017). Tax Evasion and Inequality. NBER Working Paper 23772. National Bureau of Economic Research.

Alvaredo, Facundo and Leonardo Gasparini (2015). 'Recent Trends in Inequality and Poverty in Developing Countries', in Anthony B. Atkinson and F. Bourguignon eds. Handbook of Income Distribution, vol. 2, North-Holland/Elsevier, Amsterdam, pp. 697-805.

Alvaredo, Facundo, Anthony B. Atkinson, Thomas Piketty and Emmanuel Saez (Sept. 2013). 'The Top 1 Percent in International and Historical Perspective'. In: Journal of Economic Perspectives 27.3, pp. 3-20.

Alvaredo, Facundo, Lucas Chancel, Thomas Piketty, Emmanuel Saez and Gabriel Zucman (2018). World inequality report 2018. Belknap Press of Harvard University Press.

Anderson, Edward, Maria Ana Jalles D'Orey, Maren Duvendack and Lucio Esposito (2017). 'Does government spending affect income inequality? A meta-regression analysis'. In: Journal of Economic Surveys 31.4, pp. 961-987.

Anderson, Eric, Sergio Rebelo and Arlene Wong (Mar. 2018). Markups Across Space and Time. NBER Working Paper 24434. National Bureau of Economic Research.

Arkolakis, Costas, Arnaud Costinot, Dave Donaldson and Andres Rodriguez-Clare (2018). 'The Elusive Pro-Competitive Effects of Trade'. In: The Review of Economic Studies, rdx075.

Atkin, David, Amit K. Khandelwal and Adam Osman (2017). 'Exporting and Firm Performance: Evidence from a Randomized Experiment*'. In: The Quarterly Journal of Economics 132.2, pp. 551-615.

Atkinson, Anthony B. (2015). Inequality. Harvard University Press.

Atkinson, Anthony B. and Francois Bourguignon (2015). Handbook of Income Distribution, vol. 2, North-Holland/Elsevier, Amsterdam.

Atkinson, Anthony B. and Salvatore Morelli (Nov. 2011). Economic crises and Inequality. Human Development Research Papers (2009 to present) HDRP-2011-06. Human Development Report Office (HDRO), United Nations Development Programme (UNDP). 
Atkinson, Anthony B. and Thomas Piketty, eds. (2007). Top Incomes Over the Twentieth Century: A Contrast Between Continental European and English-Speaking Countries. Oxford University Press, Oxford.

- eds. (2010). Top Incomes: A Global Perspective. Oxford University Press, Oxford.

Atkinson, Anthony B., Thomas Piketty and Emmanuel Saez (Mar. 2011). 'Top Incomes in the Long Run of History'. In: Journal of Economic Literature 49.1, pp. 3-71.

Atkinson, Anthony B., L. Rainwater and T. Smeeding (1995). Income Distribution in European Countries. Cambridge Working Papers in Economics 9535. Faculty of Economics, University of Cambridge.

Atkinson, Anthony B., Joe Hassel, Salvatore Morelli and Max Roser (May 2017). The Chartbook of Economic Inequality. Working Paper. Institute for New Economic Thinking. URL: https: //chartbookofeconomicinequality.com.

Autor, David and David Dorn (2013). The Growth of Low-Skill Service Jobs and the Polarization of the US Labor Market'. In: American Economic Review 103.5, pp. 1553-1597.

Autor, David, David Dorn, Gordon Hanson and Kaveh Majlesi (Sept. 2016). Importing Political Polarization? The Electoral Consequences of Rising Trade Exposure. NBER Working Paper 22637. National Bureau of Economic Research.

Autor, David, David Dorn, Lawrence F. Katz, Christina Patterson and John Van Reenen (May 2017). The Fall of the Labor Share and the Rise of Superstar Firms. NBER Working Paper 23396. National Bureau of Economic Research.

Autor, David H., David Dorn and Gordon H. Hanson (2016). 'The China Shock: Learning from Labor-Market Adjustment to Large Changes in Trade'. In: Annual Review of Economics 8.1, pp. 205-240.

Azar, José, Ioana Marinescu and Marshall I Steinbaum (Dec. 2017). Labor Market Concentration. NBER Working Paper 24147. National Bureau of Economic Research.

Azar, Joséand Xavier Vives (Aug. 2018). Oligopoly, Macroeconomic Performance, and Competition Policy. CESifo Working Paper Series 7189. CESifo Group Munich.

Balsvik, Ragnhild, Sissel Jensen and Kjell G. Salvanes (2015). 'Made in China, sold in Norway: Local labor market effects of an import shock'. In: Journal of Public Economics 127, pp. $137-144$.

Bargain, Olivier, Kristian Orsini and Andreas Peichl (2014). 'Comparing Labor Supply Elasticities in Europe and the United States: New Results'. In: Journal of Human Resources 49.3, pp. 723-838.

Bargain, Olivier, Tim Callan, Karina Doorley and Claire Keane (2017). 'Changes in Income Distributions and the Role of Tax-Benefit Policy During the Great Recession: An International Perspective'. In: Fiscal Studies 38.4, pp. 559-585.

Barkai, Simcha (2016). Declining Labor and Capital Shares. Stigler Center for the Study of the Economy and the State - New Working Paper Series 2.

Barth, Erling and Harald Dale-Olsen (2009). 'Monopsonistic discrimination, worker turnover, and the gender wage gap'. In: Labour Economics 16.5, pp. $589-597$.

Barth, Erling, Alex Bryson, James C. Davis and Richard Freeman (Sept. 2014). It's Where You Work: Increases in Earnings Dispersion across Establishments and Individuals in the U.S. NBER Working Paper 20447. National Bureau of Economic Research.

Bazot, Guillaume (2018). 'Financial Consumption and the Cost of Finance: Measuring Financial Efficiency in Europe (1950-2007)'. In: Journal of the European Economic Association 16.1, pp. 123-160. 
Behrens, Kristian, Giordano Mion, Yasusada Murata and Jens Sudekum (2014). 'Trade, wages and productivity'. In: International Economic Review 55.4, pp. 1305-1348.

Bell, Brian and John Van Reenen (2014). 'Bankers and Their Bonuses'. In: The Economic Journal 124.574, F1-F21.

Benmelech, Efraim, Nittai Bergman and Hyunseob Kim (Feb. 2018). Strong Employers and Weak Employees: How Does Employer Concentration Affect Wages? NBER Working Paper 24307. National Bureau of Economic Research.

Berton, Fabio, Matteo Richiardi and Stefano Sacchi (2012). The political economy of work security and flexibility: Italy in comparative perspective. 1st ed. Bristol University Press.

Bivens, Josh (2015). Gauging the impact of the Fed on inequality during the Great Recession. Working Paper 12.

Blanchard, Olivier and Francesco Giavazzi (2003). 'Macroeconomic Effects of Regulation and Deregulation in Goods and Labor Markets'. In: The Quarterly Journal of Economics 118.3, pp. 879907.

Blonigen, Bruce A. and Justin R. Pierce (Oct. 2016). Evidence for the Effects of Mergers on Market Power and Efficiency. NBER Working Paper 22750. National Bureau of Economic Research.

Bloom, Nicholas, Mirko Draca and John Van Reenen (2016). 'Trade Induced Technical Change? The Impact of Chinese Imports on Innovation, IT and Productivity'. In: The Review of Economic Studies 83.1, pp. 87-117.

Booth, Alison L., Marco Francesconi and Jeff Frank (June 2002). ${ }^{\circ}$ Temporary Jobs: Stepping Stones Or Dead Ends?' In: Economic Journal 112.480, pp. 189-213.

Borrs, Linda and Florian Knauth (2016). The impact of trade and technology on wage components. DICE Discussion Papers 241. University of Dusseldorf, Dusseldorf Institute for Competition Economics (DICE).

Bottasso, Anna and Alessandro Sembenelli (2001). 'Market power, productivity and the EU Single Market Program: Evidence from a panel of Italian firms'. In: European Economic Review 45.1, pp. $167-186$.

Bourguignon, F (2015). The Globalization of Inequality. Princeton University Press.

Boustanifar, Hamid, Everett Grant and Ariell Reshef (2018). 'Wages and Human Capital in Finance: International Evidence, 1970-2011*'. In: Review of Finance 22.2, pp. 699-745.

Bresnahan, Timothy F. (1989). 'Empirical studies of industries with market power'. In: vol. 2. Handbook of Industrial Organization. Elsevier, pp. 1011 -1057.

Brun, Lidia and Ignacio Gonzalez (2017). Tobin's $\mathcal{Q}$ and Inequality. Working Paper. Dol: http: //dx.doi.org/10.2139/ssrn. 3069980.

Bustillo, Inés., Raquel Artecona and Daniel Perrotti (2018). Inequality and Growth in Latin America: Acbievements and Challenges, Working Paper, Group of 24 and Friedrich-Ebert-Stiftung, New York.

Cabral, L.M.B. (2017). Introduction to Industrial Organization, Second edition. MIT Press. Cacciatore, Matteo and Giuseppe Fiori (Dec. 2015). 'The Macroeconomics of Market Regulation'. In: International Finance 18.3, pp. 343-360.

Card, David (1996). 'The Effect of Unions on the Structure of Wages: A Longitudinal Analysis'. In: Econometrica 64.4, pp. 957-979.

- (May 2009). 'Immigration and Inequality'. In: American Economic Review 99.2, pp. 1-21. Card, David, Jorg Heining and Patrick Kline (2013). 'Workplace Heterogeneity and the Rise of

West German Wage Inequality'. In: The Quarterly Journal of Economics 128.3, pp. 967-1015. Causa,

Orsetta and Mikkel Hermansen (2017). 'Income redistribution through taxes and transfers across OECD countries'. In: OECD Economics Department Working Papers 1453. 
CEA (Apr. 2016). Benefits of competition and indicators of market power. Issue Brief. Council of Economic Advisers. URL: https://obamawhitehouse.archives.gov/sites/default/files/ page/files/20160414_cea_competition_issue_brief.pdf (visited on 30/10/2018).

Cecchetti, Stephen G and Enisse Kharroubi (Feb. 2015). Why does financial sector growth crowd out real economic growth? BIS Working Papers 490. Bank for International Settlements.

Chen, Natalie, Jean Imbs and Andrew Scott (2009). "The dynamics of trade and competition'. In: Journal of International Economics 77.1, pp. 50 -62.

Chusseau, Nathalie, Michel Dumont and Joel Hellier (2008). 'Explaining rising inequality: skill-biased technical change and north-south trade'. In: Journal of Economic Surveys 22.3, pp. 409- 457 .

Coibion, Olivier, Yuriy Gorodnichenko, Lorenz Kueng and John Silvia (2017). Innocent Bystanders? Monetary policy and inequality'. In: Journal of Monetary Economics 88, pp. 70 -89.

Crespi, Gustavo, Chiara Criscuolo and Jonathan Haskel (2008). 'Productivity, Exporting, and the Learning-by-Exporting Hypothesis: Direct Evidence from UK Firms'. In: The Canadian Journal of Economics / Revue canadienne d'Economique 41.2, pp. 619-638.

Crino, Rosario (2009). 'Offshoring, multinationals and labour market: a review of the empirical literature'. In: Journal of Economic Surveys 23.2, pp. 197-249.

Crozet, Matthieu and Gianluca Orefice (2017). Trade and Labor Market: What Do We Know? CEPII Policy Brief. CEPII Research Center.

Cuñat, Vicente and Maria Guadalupe (2009a). 'Executive compensation and competition in the banking and financial sectors'. In: Journal of Banking \& Finance 33.3, pp. $495-504$.

- (2009b). 'Globalization and the Provision of Incentives inside the Firm: The Effect of Foreign Competition'. In: Journal of Labor Economics 27.2, pp. 179-212.

Dabla-Norris, Era, Kalpana Kochhar, Nujin Suphaphiphat, Frantisek Ricka and Evridiki Tsounta (2015). Causes and Consequences of Income Inequality: A Global Perspective. IMF Staff Discussion Note SDN/15/13.

Dauth, Wolfgang, Sebastian Findeisen and Jens Suedekum (2014). The Rise of the East and the Far East: German Labor Markets and Trade Integration'. In: Journal of the European Economic Association 12.6, pp. 1643-1675.

Dauth, Wolfgang, Sebastian Findeisen, Jens Suedekum and Nicole Woessner (Sept. 2017). German Robots - The Impact of Industrial Robots on Workers. CEPR Discussion Papers 12306.

Davis, Steven J. and John Haltiwanger (Sept. 2014). Labor Market Fluidity and Economic Performance. NBER Working Paper 20479. National Bureau of Economic Research.

De Agostini, Paola, Alari Paulus, Holly Sutherland and Iva Valentinova Tasseva (May 2014). The effect of tax-benefit changes on the income distribution in EU countries since the beginning of the economic crisis. EUROMOD Working Papers EM9/14. EUROMOD at the Institute for Social and Economic Research.

De Loecker, Jan (Aug. 2013). 'Detecting Learning by Exporting'. In: American Economic Journal: Microeconomics 5.3, pp. 1-21.

De Loecker, Jan and Jan Van Biesebroeck (2018). 'Effect of International Competition on Firm Productivity and Market Power'. In: Oxford Handbook of Productivity Analysis. Ed. by Emili Grifell-Tatjé, C. A. Knox Lovell and Robin C. Sickles. Oxford University Press, Oxford, pp. 463-492.

De Loecker, Jan and Jan Eeckhout (Aug. 2017). The Rise of Market Power and the Macroeconomic Implications. NBER Working Paper 23687. National Bureau of Economic Research. 
De Loecker, Jan and Jan Eeckhout (June 2018). Global Market Power. NBER Working Paper 24768. National Bureau of Economic Research.

De Loecker, Jan, Pinelopi K. Goldberg, Amit K. Khandelwal and Nina Pavcnik (2016). 'Prices, Markups, and Trade Reform'. In: Econometrica 84.2, pp. 445-510.

Demsetz, Harold (1973). 'Industry Structure, Market Rivalry, and Public Policy'. In: The Journal of Law and Economics 16.1, pp. 1-9.

Denk, Oliver (2015). Who are the top 1\% earners in Europe? OECD Economics Department Working Papers 1274.

Depew, Briggs and Todd Sorensen (2013). 'The elasticity of labor supply to the firm over the business cycle'. In: Labour Economics 24.C, pp. 196-204.

Deutsche Bundesbank (Dec. 2017). Mark-ups of firms in selected European countries. Monthly Report 53. Deutsche Bundesbank.

Dew-Becker, Ian and Robert J Gordon (Dec. 2005). Where Did the Productivity Growth Go? Inflation Dynamics and the Distribution of Income. NBER Working Paper 11842. National Bureau of Economic Research.

Diez, Federico, Daniel Leigh and Suchanan Tambunlertchai (2018). Global Market Power and its Macroeconomic Implications. IMF Working Paper 18/137.

Dolls, Mathias, Clemens Fuest and Andreas Peichl (2011). 'Automatic Stabilizers, Economic Crisis and Income Distribution in Europe'. In: Who Loses in the Downturn? Economic Crisis, Employment and Income Distribution, pp. 227-255.

Domanski, Dietrich, Michela Scatigna and Anna Zabai (2016). 'Wealth inequality and monetary policy'. In: BIS Quarterly Review.

Douglas, Webber (2016). 'Firm-Level Monopsony and the Gender Pay Gap'. In: Industrial Relations: A Journal of Economy and Society 55.2, pp. 323-345.

Dube, Arindrajit, T. William Lester and Michael Reich (2010). 'Minimum Wage Effects Across State Borders: Estimates Using Contiguous Counties'. In: The Review of Economics and Statistics 92.4, pp. 945-964.

Dunhaupt, Petra (2017). 'Determinants of labour's income share in the era of financialisation'. In: Cambridge Journal of Economics 41.1, pp. 283-306.

Dustmann, Christian, Tommaso Frattini and Ian P. Preston (2013). 'The Effect of Immigration along the Distribution of Wages'. In: The Review of Economic Studies 80.1, pp. 145-173.

Ebenstein, Avraham, Ann Harrison, Margaret McMillan and Shannon Phillips (2014). 'Estimating the Impact of Trade and Offshoring on American Workers using the Current Population Surveys'. In: The Review of Economics and Statistics 96.4, pp. 581-595.

Edmond, Chris, Virgiliu Midrigan and Daniel Yi Xu (2015). 'Competition, Markups, and the Gains from International Trade'. In: The American Economic Review 105.10, pp. 3183-3221.

Epstein, Gerald (2005). Financialization and the World Economy. Edward Elgar Pub.

Fagereng, Andreas, Luigi Guiso, Davide Malacrino and Luigi Pistaferri (2018). Heterogeneity and Persistence in Returns to Wealth. CESifo Working Paper Series 7107. CESifo Group Munich.

Falch, Torberg (2010). 'The Elasticity of Labor Supply at the Establishment Level'. In: Journal of Labor Economics 28.2, pp. 237-266.

- (May 2011). 'Teacher Mobility Responses to Wage Changes: Evidence from a Quasi-natural Experiment'. In: American Economic Review 101.3, pp. 460-65.

Fan, Haichao, Xiang Gao, Yao Amber Li and Tuan Anh Luong (2018). 'Trade liberalization and markups: Micro evidence from China'. In: Journal of Comparative Economics 46.1, pp. 103 -130. 
Farber, Henry S, Daniel Herbst, Ilyana Kuziemko and Suresh Naidu (May 2018). Unions and Inequality Over the Twentieth Century: New Evidence from Survey Data. NBER Working Paper 24587. National Bureau of Economic Research.

Feenstra, Robert C. and David E. Weinstein (2017). 'Globalization, Markups, and US Welfare'. In: Journal of Political Economy 125.4, pp. 1040-1074.

Felix, Sonia and Pedro Portugal (2017). Labor market imperfections and the firm's wage setting policy. Working Papers. Banco de Portugal, Economics and Research Department.

Foliano, Francesca and Rebecca Riley (2017). 'International Trade and UK de-industrialisation'. In: National Institute Economic Review 242.1, R3-R13.

Forster, Michael F. and Istvan Gyorgy Toth (2015). 'Cross-Country Evidence of the Multiple Causes of Inequality Changes in the OECD Area'. In: Handbook of Income Distribution. Ed. by Anthony B. Atkinson and François Bourguignon. Vol. 2. Handbook of Income Distribution. Elsevier, pp. $1729-1843$.

Freeman, Richard B. (2008). 'Globalization and Inequality', in Brian Nolan, Wiemer Salverda, and Timothy M. Smeeding eds., The Oxford Handbook of Economic Inequality, Oxford University Press, Oxford.

Fuest, Clemens, Andreas Peichl and Sebastian Siegloch (Feb. 2018). 'Do Higher Corporate Taxes Reduce Wages? Micro Evidence from Germany'. In: American Economic Review 108.2, pp. 393- 418.

Gabaix, Xavier, Jean-Michel Lasry, Pierre-Louis Lions and Benjamin Moll (2016). The Dynamics of Inequality'. In: Econometrica 84.6, pp. 2071-2111.

Galbraith, James K. (2012). Inequality and Instability: A Study of the World Economy Just Before the Great Crisis. Oxford University Press, Oxford.

Galli, R. and R. van der Hoeven (2001). Is Inflation Bad for Income Inequality: The Importance of the Initial Rate of Inflation. Cahiers de l'emploi. Employment Sector, International Labour Office.

Garcia, Joao (2015). Is low worker mobility evidence for monopsony power?' URL: http : / / leed2015.tecnico.ulisboa.pt/program/pdfs/Garcia.pdf (visited on 30/10/2018).

Garicano, Luis and Esteban Rossi-Hansberg (2006). 'Organization and Inequality in a Knowledge Economy*'. In: The Quarterly Journal of Economics 121.4, pp. 1383-1435.

Gasparini, Leonardo and Leopoldo Tornarolli (Dec. 2015). 'A review of the OECD Income Distribution Database'. In: The Journal of Economic Inequality 13.4, pp. 579-602.

Girma, Sourafel, Avid Greenaway and Richard Kneller (2004). 'Does Exporting Increase Productivity? A Microeconometric Analysis of Matched Firms'. In: Review of International Economics 12.5, pp. 855-866.

Goldin, Claudia and Lawrence Katz (2008). The Race Between Education and Technology. Harvard University Press.

Goldstein, Joshua R. and Ronald D. Lee (2014). 'How large are the effects of population aging on economic inequality?' In: Vienna Yearbook of Population Research 12, pp. 193-209.

Gonzalez, Libertad and Tanya Surovtseva (June 2016). 'Stepping Up: Male Unemployment and Female Participation during the Great Recession'. URL: https://editorialexpress.com/cgibin/conference/download.cgi?db name=SAEe2016 \&paper id=242 (visited on 30/10/2018).

Goos, Maarten, Alan Manning and Anna Salomons (2014). 'Explaining Job Polarization: Routine-Biased Technological Change and Offshoring'. In: American Economic Review 104.8, pp. 2509- 26.

Gornick, J. and M. Jãntti (2013). Income Inequality: Economic Disparities and the Middle Class in Affluent Countries. Studies in Social Inequality. Stanford University Press. 
Graetz, Georg and Guy Michaels (Feb. 2018). Robots at Work'. URL: http://personal.1se.ac. $\mathrm{uk} / \mathrm{mi}$ chaels/Graetz Michaels Robots.pdf (visited on 30/10/2018).

Greenaway, David and Richard Kneller (2007). 'Firm heterogeneity, exporting and foreign direct investment'. In: The Economic Journal 117.517, F134-F161.

Greenwood, Jeremy, Nezih Guner, Georgi Kocharkov and Cezar Santos (May 2014). 'Marry Your Like: Assortative Mating and Income Inequality'. In: American Economic Review 104.5, pp. 348- 53.

- (Jan. 2016). 'Technology and the Changing Family: A Unified Model of Marriage, Divorce, Educational Attainment, and Married Female Labor-Force Participation'. In: American Economic Journal: Macroeconomics 8.1, pp. 1-41.

Griliches, Zvi (1969). 'Capital-Skill Complementarity'. In: The Review of Economics and Statistics 51.4, pp. 465-468.

Grullon, Gustavo, Yelena Larkin and Roni Michaely (2017). Are U.S. Industries Becoming More Concentrated? Working Paper. DOT: http://dx.doi.org/10.2139/ssrn.2612047.

Guschanski, Alexander and Ozlem Onaran (July 2017). The political economy of income distribution: industry level evidence from 14 OECD countries. London.

Gutierrez, German (2017). Investigating Global Labor and Profit Shares. Working Paper. DOT: https://dx.doi.org/10.2139/ssrn.3040853.

Gutierrez, German and Thomas Philippon (Dec. 2016). Investment-less Growth: An Empirical Investigation. NBER Working Paper 22897. National Bureau of Economic Research.

Guvenen, Fatih, Greg Kaplan and Jae Song (May 2014). 'How Risky Are Recessions for Top Earners?' In: American Economic Review 104.5, pp. 148-53.

Hacker, Jacob S. (2008). The Great Risk Shift: The New Economic Insecurity and the Decline of the American Dream. Oxford University Press, Oxford.

Hakobyan, Shushanik and John McLaren (2016). 'Looking for Local Labor Market Effects of NAFTA'. In: The Review of Economics and Statistics 98.4, pp. 728-741.

Hall, Robert E (May 2018). New Evidence on the Markup of Prices over Marginal Costs and the Role of Mega-Firms in the US Economy. NBER Working Paper 24574. National Bureau of Economic Research.

Han, Minsoo (2015). Rising Income Inequality and Competition: Evidence. KIEP Research Papers Working Papers 14-03. DOT: https://dx.doi.org/10.2139/ssrn.2634311.

Harrison, Ann (2005). Has Globalization Eroded Labor's Share? Some Cross-Country Evidence. MPRA Paper 39649. University Library of Munich, Germany.

Harrison, Ann, John McLaren and Margaret McMillan (2011). 'Recent Perspectives on Trade and Inequality'. In: Annual Review of Economics 3.1, pp. 261-289.

Hein, Eckhard (2015). 'Finance-dominated capitalism and re-distribution of income: a Kaleckian perspective'. In: Cambridge Journal of Economics 39.3, pp. 907-934.

Helpman, Elhanan (Dec. 2016). Globalization and Wage Inequality. NBER Working Paper 22944. National Bureau of Economic Research.

Hirsch, Boris, Thorsten Schank and Claus Schnabel (2010). 'Differences in Labor Supply to Monopsonistic Firms and the Gender Pay Gap: An Empirical Analysis Using Linked Employer-Employee Data from Germany'. In: Journal of Labor Economics 28.2, pp. 291-330.

Hornbeck, Richard and Enrico Moretti (May 2018). Who Benefits From Productivity Growth? Direct and Indirect Effects of Local TFP Growth on Wages, Rents, and Inequality. NBER Working Paper 24661. National Bureau of Economic Research. 
Hotchkiss, Julie L., Myriam Quispe-agnoli and Federico Mandelman (2012). Employer Monopsony Power in the Labor Market for Undocumented Workers.

Howes, Candace (2005). 'Living Wages and Retention of Homecare Workers in San Francisco'. In: Industrial Relations: A Journal of Economy and Society 44.1, pp. 139-163.

Hoynes, Hilary and Diane Whitmore Schanzenbach (2012). 'Work incentives and the Food Stamp Program'. In: Journal of Public Economics 96.1, pp. 151-162.

Hummels, David, Jakob R. Munch and Chong Xiang (Feb. 2016). Offshoring and Labor Markets. NBER Working Paper 22041. National Bureau of Economic Research.

Immervoll, Herwig and Linda Richardson (Oct. 2011). Redistribution Policy and Inequality Reduction in OECD Countries: What Has Changed in Two Decades? OECD Social, Employment and Migration Working Papers 122. OECD Publishing.

Jaumotte, Florence, Subir Lall and Chris Papageorgiou (June 2013). 'Rising Income Inequality:

Technology, or Trade and Financial Globalization?' In: IMF Economic Review 61.2, pp. 271-309.

Jayadev, Arjun (2007). 'Capital account openness and the labour share of income'. In: Cambridge Journal of Economics 31.3, pp. 423-443.

Jenkins, Stephen P., Andrea Brandolini, John Micklewright and Brian Nolan, eds. (2013). The Great Recession and the Distribution of Household Income. Oxford University Press, Oxford. Joumard,

Isabelle, Mauro Pisu and Debbie Bloch (2012). 'Tackling income inequality'. In: OECD

Journal: Economic Studies 2012/1.

Kanbur, R. (2015). 'Globalization and Inequality', in Anthony B. Atkinson and F. Bourguignon eds. Handbook of Income Distribution, vol. 2, North-Holland/Elsevier, Amsterdam, pp. 1845-1881.

Keller, Wolfgang and William W. Olney (Feb. 2018). Globalization and Executive Compensation. Department of Economics Working Papers 2018-02. Department of Economics, Williams College.

Kierzenkowski, Rafal and Isabell Koske (2012). 'Less Income Inequality and More Growth - Are they Compatible? Part 8. The Drivers of Labour Income Inequality - A Literature Review'. In: OECD Economics Department Working Papers 931.

Klaus Walde and Pia Weiss (2007). 'International competition, downsizing and wage inequality'. In: Journal of International Economics 73.2, pp. 396 -406.

Konings, Jozef and Hylke Vandenbussche (2005). 'Antidumping protection and markups of domestic firms'. In: Journal of International Economics 65.1, pp. $151-165$.

Koren, Miklos and Marton Csillag (Aug. 2017). 'Machines and Machinists: Importing Skill-Biased Technology'. URL: http: / /miklos . koren. hu / static / pdf /machines . pdf (visited on 30/10/2018).

Kristal, Tali (2010). 'Good Times, Bad Times: Postwar Labor's Share of National Income in Capitalist Democracies'. In: American Sociological Review 75.5, pp. 729-763.

Krugman, Paul (2016). Trade and Manufacturing Employment: No Real Disagreement. URL: https: // www. gc.cuny. edu/CUNY GC/media/LISCenter/pkrugman/Trade-and-ManufacturingEmployment.pdf (visited on 30/10/2018).

Kurokawa, Yoshinori (2014). 'A survey of trade and wage inequality: anomalies, resolutions and new trends'. In: Journal of Economic Surveys 28.1, pp. 169-193.

Levinsohn, James (1993). 'Testing the imports-as-market-discipline hypothesis'. In: Journal of International Economics 35.1, pp. 1 -22.

Ma, Wenting, Paige Ouimet and Elena Simintzi (June 2016). Mergers and Acquisitions, Technological Change and Inequality. European Corporate Governance Institute (ECGI) - Finance Working Paper 485/2016. DОт: http://dx. doi.org/10.2139/ssrn.2793887. 
Manacorda, Marco, Alan Manning and Jonathan Wadsworth (2012). The impact of immigration on the structure of wages: theory and evidence from Britain'. In: Journal of the European Economic Association 10.1, pp. 120-151.

Manning, Alan (2011). 'Imperfect Competition in the Labor Market'. In: ed. by O. Ashenfelter and D. Card. 1st ed. Vol. 4B. Elsevier. Chap. 11, pp. 973-1041.

Manyika, James, Sree Ramaswamy, Jacques Bughin, Jonathan Woetzel, Michael Birshan and Zubin Nagpal (Oct. 2018). 'Superstars': The dynamics of firms, sectors, and cities leading the global economy. Working Paper. McKinsey Global Institute.

Mason, J.W. (2015). Disgorge the Cash: The Disconnect Between Corporate Borrowing and Investment. URL: http://rooseveltinstitute.org/disgorge- cash- disconnect- betweencorporate-borrowing-and-investment-1/ (visited on 30/10/2018).

Milanovic, Branco (2016). Global Inequality: A New Approach for the Age of Globalization. Harvard University Press.

Milanovic, Branko and Roy van der Weide (2018). 'Inequality is Bad for Growth of the Poor (but Not for That of the Rich)'. In: The World Bank Economic Review 32.3, pp. 507-530.

Molloy, Raven, Christopher L. Smith and Abigail K. Wozniak (Apr. 2014). Declining Migration within the U.S.: The Role of the Labor Market. NBER Working Paper 20065. National Bureau of Economic Research.

Monnin, Pierre (May 2014). Inflation and Income Inequality in Developed Economies. Working Papers 1401. Council on Economic Policies.

Morelli, Salvatore (2018). 'Banking crises in the US: the response of top income shares in a historical perspective'. In: The Journal of Economic Inequality 16.2, pp. 257-294.

MSGI (2016). Are CEOs Paid for Performance? URL: https://www.msci.com/www/researchpaper/are- ceos-paid-for-performance-/0412607620 (visited on 30/10/2018).

Mumtaz, Haroon and Angeliki Theophilopoulou (2017). The impact of monetary policy on inequality in the UK. An empirical analysis'. In: European Economic Review 98, pp. $410-423$.

Nallareddy, Suresh, Ethan Rouen and Juan Carlos Suárez Serrato (May 2018). Do Corporate Tax Cuts Increase Income Inequality? NBER Working Paper 24598. National Bureau of Economic Research.

Nilsson Hakkala, Katariina and Kristiina Huttunen (July 2016). Worker-Level Consequences of Import Shocks. IZA Discussion Papers 10033. Institute for the Study of Labor (IZA).

Nolan, Brian, ed. (2018). Inequality and Inclusive Growth in Rich Countries: Shared Challenges and Contrasting Fortunes. Oxford University Press, Oxford.

Nolan, Brian, Wiemer. Salverda, Daniele Checchi, Ive Marx, Abigail. McKnight, Istvan Gyorgy Toth and Herman van der Werfhort, eds. (2014). Changing Inequalities and Societal Impacts in Rich Countries: Thirty Countries' Experiences. Oxford University Press, Oxford.

Nolan, Brian, Ebrahim Rebhari, Matteo Richiardi, Luis Valenzuela, and Benjamin Nabarro (2017). Prosperity and Inequality in the Industrialized World: Addressing a Growing Challenge, Citi Global Perspectives and Solutions, Citi, London.

OECD (1994). The OECD jobs study: evidence and explanations. OECD Publishing, Paris.

- (2008). Growing Unequal?: Income Distribution and Poverty in OECD Countries. OECD Publishing, Paris.

- (2010). Measuring Globalisation: OECD Economic Globalisation Indicators 2010. OECD Publishing, Paris.

- (2011). Divided We Stand: Why Inequality Keeps Rising. OECD Publishing, Paris.

- (2012). OECD Employment Outlook 2012. OECD Publishing, Paris.

- (2015). In It Together: Why Less Inequality Benefits All. OECD Publishing, Paris. 
Ottaviano, Gianmarco and Giovanni Peri (2012). 'Rethinking the effect of immigration on wages'. In: Journal of the European Economic Association 10.1, pp. 152-197.

O'Farrell, Rory, Lukasz Rawdanowicz and Kei-Ichiro Inaba (2016). Monetary Policy and Inequality. OECD Economics Department Working Papers 1281.

Parker, Jonathan A. and Annette Vissing-Jorgensen (May 2009). 'Who Bears Aggregate Fluctuations and How?' In: American Economic Review 99.2, pp. 399-405.

Perri, Fabrizio and Joe Steinberg (2012). Inequality and redistribution during the Great Recession. Economic Policy Paper 12-1. Federal Reserve Bank of Minneapolis.

Peters, Heiko and Maya Volwahsen (Dec. 2016). Rising income inequality: do not draw the obvious conclusions'. URL: https : / / WWT . dbresearch . com / PROD / RPS EN - PROD / PROD0000000000441786/Rising_income_inequality3A_do_not_draw_the_obvious_.pdf (visited on 30/10/2018).

Philippon, Thomas (2015). 'Has the US Finance Industry Become Less Efficient? On the Theory and Measurement of Financial Intermediation'. In: American Economic Review 105.4, pp. 1408-38. Philippon, Thomas and Ariell Reshef (2012). 'Wages and Human Capital in the U.S. Finance Industry: 1909-2006*'. In: The Quarterly Journal of Economics 127.4, pp. 1551-1609.

Piketty, Thomas (2014). Capital in the Twenty-First Century. Harvard University Press.

Piketty, Thomas and Emmanuel Saez (2007). 'How Progressive is the U.S. Federal Tax System? A Historical and International Perspective'. In: Journal of Economic Perspectives 21.1, pp. 3-24.

Piketty, Thomas, Emmanuel Saez and Stefanie Stantcheva (Feb. 2014). 'Optimal Taxation of Top Labor Incomes: A Tale of Three Elasticities'. In: American Economic Journal: Economic Policy 6.1, pp. $230-71$.

Piketty, Thomas, Emmanuel Saez and Gabriel Zucman (2018). 'Distributional National Accounts: Methods and Estimates for the United States*'. In: The Quarterly Journal of Economics 133.2, pp. 553-609.

Ransom, Michael R. and Ronald L. Oaxaca (2010). 'New Market Power Models and Sex Differences in Pay'. In: Journal of Labor Economics 28.2, pp. 267-289.

Ransom, Michael R. and David P. Sims (2010). 'Estimating the Firm's Labor Supply Curve in a "New Monopsony" Framework: Schoolteachers in Missouri'. In: Journal of Labor Economics 28.2, pp. 331-355.

Ravallion, Martin (2015). 'The Luxembourg Income Study'. In: The Journal of Economic Inequality 13.4, pp. 527-547.

- (June 2018). 'Inequality and Globalization: A Review Essay'. In: Journal of Economic Literature 56.2, pp. 620-42.

Reenen, John Van (Sept. 2018). Increasing Differences Between Firms: Market Power and the Macro-Economy. CEP Discussion Paper 1576.

Reich, Michael, Peter Hall and Ken Jacobs (2005). 'Living Wage Policies at the San Francisco Airport: Impacts on Workers and Businesses'. In: Industrial Relations: A Journal of Economy and Society 44.1, pp. 106-138.

Rosen, Sherwin (1981). 'The Economics of Superstars'. In: American Economic Review 71.5, pp. 84558.

Rossi-Hansberg, Esteban, Pierre-Daniel Sarte and Nicholas Trachter (Sept. 2018). Diverging Trends in National and Local Concentration. NBER Working Paper 25066. National Bureau of Economic Research. 
Rovo, Natasha (2017). 'Essays on Secular Stagnation'. PhD Thesis. LUISS Guido Carli. url: http://eprints.luiss.it/1482/1/20170517-rovo.pdf (visited on 30/10/2018).

Salverda, Wiemer, Brian Nolan, Daniele Checchi, Ive Marx, Abigail McKnight, Istvan Gyorgy Toth and Herman van Werfhorst, eds. (2014). Changing Inequalities in Rich Countries: Analytical and Comparative Perspectives. Oxford University Press, Oxford.

Shepotylo, Oleksandr and Volodymyr Vakhitov (2012). Wage inequality and trade reform: productivity channel. Tech. rep. url: https : / / www . hhs . se / contentassets / db23f51be5de4c55bd92138c1037e466/shepotylo-paper-2.pdf (visited on 30/10/2018).

Smeeding, Timothy M. and Jeffrey P. Thompson (July 2013). Inequality and Poverty in the United States: The Aftermath of the Great Recession. FEDS Working Paper 2013-51.

Solow, Robert M. (1957). 'Technical Change and the Aggregate Production Function'. In: The Review of Economics and Statistics 39.3, pp. 312-320.

Solow, Robert M (1990). The labor market as a social institution. Cambridge, MA : B. Blackwell. Song, Jae, David J Price, Fatih Guvenen, Nicholas Bloom and Till von Wachter (2019). 'Firming Up Inequality'. In: The Quarterly Journal of Economics 134.1, pp. 1-50.

Staiger, Douglas O., Joanne Spetz and Ciaran S. Phibbs (2010). 'Is There Monopsony in the Labor Market? Evidence from a Natural Experiment'. In: Journal of Labor Economics 28.2, pp. 211-236. Stiglitz, Joseph (2012). The Price of Inequality. W.W. Norton \& Company.

- (2015). The Great Divide: Unequal Societies and What We Can Do About Them. W.W. Norton \& Company.

Tanndal, Julia and Daniel Waldenstrom (2018). 'Does Financial Deregulation Boost Top Incomes? Evidence from the Big Bang'. In: Economica 85.338, pp. 232-265.

Tinbergen, Jan (1975). Income distribution: analysis and policies. North-Holland Pub. Co.

Traina, James (Feb. 2018). Is Aggregate Market Power Increasing? Production Trends Using Financial Statements. Stigler Center for the Study of the Economy and the State - New Working Paper Series 17.

Tridico, Pasquale (2018). 'The determinants of income inequality in OECD countries'. In: Cambridge Journal of Economics 42.4, pp. 1009-1042.

Tybout, James R. (2008). 'Plant- and Firm-Level Evidence on "New" Trade Theories'. In: Handbook of International Trade. Wiley-Blackwell. Chap. 13, pp. 388-415.

TØrslØv, Thomas R, Ludvig S Wier and Gabriel Zucman (June 2018). The Missing Profits of Nations. NBER Working Paper 24701. National Bureau of Economic Research.

Wagner, Joachim (2007). 'Exports and Productivity: A Survey of the Evidence from Firmlevel Data'. In: The World Economy 30.1, pp. 60-82.

Webber, Douglas (2015). 'Firm market power and the earnings distribution'. In: Labour Economics 35.C, pp. 123-134.

Weche, John P. and Achim Wambach (2018). The Fall and Rise of Market Power in Europe. ZEW Discussion Paper 18-003.

Weisstanner, David (Nov. 2017). Dualization and inequality revisited: Temporary employment regulation and middle-class incomes. LIS Working papers 720. LIS Cross-National Data Center in Luxembourg.

Wright, Thomas and Gabriel Zucman (Sept. 2018). The Exorbitant Tax Privilege. NBER Working Paper 24983. National Bureau of Economic Research.

WTO (2013). Global value chains in a changing world. Discussion paper. 